\title{
The effect of corporate governance on the performance of US investment banks
}

\author{
BY EMMANUEL MAMATZAKIS AND THEODORA BERMPEI
}

\begin{abstract}
This paper focuses on the impact of the corporate governance, using a plethora of measures, on the performance of the US investment banks over the 2000-2012 period. This time period offers a unique set of information, related to the credit crunch, that we model using a dynamic panel threshold analysis to reveal new insights into the relationship between corporate governance and bank performance. Results show that the board size asserts a negative effect on performance consistent with the 'agency cost' hypothesis, particularly for banks with board size higher than ten members. Threshold analysis reveals that in the post-crisis period most of investment banks opt for boards with less than ten members, aiming to decrease agency conflicts that large boards suffer from. We also find a negative association between the operational complexity and performance. Moreover, the CEO power asserts a positive effect on performance consistent with the 'stewardship' hypothesis. In addition, an increase in the bank ownership held by the board has a negative impact on performance for banks below a certain threshold. On the other hand, for banks with board ownership above the threshold value this effect turns positive, indicating an alignment between shareholders' and managers' incentives.
\end{abstract}

Keywords: Investment Banking, Corporate governance, Performance, Board size, CEO power, Board Ownership.

JEL classification: G01, G21, G30, G32.

Corresponding author: Emmanuel Mamatzakis School of Business, Management and Economics, University of Sussex, Jubilee Building, Brighton, BN1 9SL, United Kingdom, e.mamatzakis@sussex.ac.uk. 


\section{INTRODUCTION}

The liberalization and globalization of financial services in combination with rapid advances in the financial innovation have broadened significantly the variety of operations in which investment banks engage in over the last two decades. Such operations include the issuance of debt or equity securities in the primary market, as well as the financial advisory services and the trading of securities in the secondary market. As a result, the performance of investment banking industry, through complex operations, is of utmost importance for the well-functioning of global financial markets. Yet, only Radic et al. (2012) appear to examine the underlying determinants of the performance of investment banks. This paper bridges this gap in the literature and further reveals a crucial link between corporate governance and the performance of these financial institutions.

Investment banking activities have been important particularly in the US economy as they captured more than half (58\%) of the global investment banking revenues in 2012, while the US investment banking accounted for $30 \%$ of the total US banking industry profits during the same year. However, the investment banking industry has also been held accountable for the credit crunch in 2008 that hit the US and then spread globally. In fact, the turmoil reveals the possible detrimental impact of the investment banking on financial market (Brunnermeier and Pederson, 2009; Demirguc-Kunt and Huizinga, 2010). Moreover, the US financial market, towards the end of the last decade, entered a period of unprecedented instability where the estimated losses due to subprime mortgages were between 400 (US\$bn) and 500 (US\$bn). Consequently, investment banks went through some very dramatic changes. Bear Stearns was acquired by JP Morgan with the financial support of the Federal Reserve Bank, Merrill Lynch had to raise a substantial volume of capital to cover high realised losses on assets, whereas Lehman Brothers filed for bankruptcy. Demirguc-Kunt and Huizinga (2010) and Acharya and Richardson (2009) argue that part of the causes of the crisis should be attributed to the 
considerably complex activities of investment banks. The shift of financial institutions from deposit-taking activities into highly complex operations might have contributed to the crisis resulting in the underperformance of investment banks and the financial system as a whole (Demirguc-Kunt and Huizinga, 2010). ${ }^{\mathrm{i}}$ The degree of complexity of investment banking activities is related closely to the corporate governance of investment banks. To this end, an inquest into the operations of investment banks necessitates a detailed study of bank corporate governance.

In this paper, we focus on the impact of the corporate governance on investment bank performance. Due to the crisis of 2008, the governance of financial institutions has been into the spotlight (Fahlenbrach and Stulz, 2011; Erkens et al., 2012; Beltratti and Stulz, 2012; Pathan and Faff, 2013;Vallascas and Hagendorff, 2013), whilst a growing perception of the destructive role of the corporate governance with respect to the performance of banks has gained support (Kirkpatrick, 2009). Providing a concrete definition of corporate governance is not an easy task. Gillan and Starks (1998) describe corporate governance as an internal mechanism that is linked closely to the system of acts, laws, and dynamics that control the operations of a firm. Therefore, the corporate governance of banks is particularly complex, as these financial institutions are unique and differ fundamentally from non-banking institutions. This in turn implies that corporate governance of banks plays an important role due to the distinctiveness of these institutions. In particular, banks have three main characteristics that motivate a separate examination of the corporate governance in banking. Firstly, according to the banking theory the nature of financial intermediation makes banks more opaque compared to other institutions due to the difficulty of outsiders to monitor bank assets (Diamond and Rajan, 2001; Levine, 2004). Moreover, the special nature of banks is reflected in the complexity of the bank business model (Furfine, 2001). The high level of operational complexity is apparent particularly in investment banks and distinguishes the business model 
of these financial institutions from that of other types of banking and non-banking institutions (Acharya and Richardson, 2009; Demirguc-Kunt and Huizinga, 2010). Therefore, the issue of bank opacity in combination with the complexity of investment banks' business model makes it difficult for the outside shareholders to monitor bank operations raising in this way information asymmetries (Andres and Vallelado, 2008).

Secondly, banks are heavily leveraged institutions and this in turn can have important implications in terms of corporate governance (Hagendorff, 2014). Banks' equity is relatively low compared to that of other institutions. However, shareholders in banks appear to control the main mechanisms of corporate governance, such as the executive compensation and the board of directors. Hence, despite the fact that creditors are more important than equity investors for the wealth of banks, the shareholders of banks have a predominant role in the governance of banks and thus can take decisions intended to maximize their own wealth. This is particularly important as shareholders are risk-neutral while creditors risk-averse and thus they have different risk preferences (Hagendorff, 2014). This in turn suggests that under high level of bank leverage the power of shareholder rises as they have a key role in the decisionmaking process of banks (Jensen and Meckling, 1976; Hagendorff, 2014). In this case, shareholders hold large claims on bank's assets and hence they are encouraged to raise risk aiming to increase their equity value. However, an increase of the bank risk would bear losses for creditors and thus this would decrease their wealth.

Thirdly, regulation plays a crucial role for banking institutions due to the importance of banks in the economy and the opacity of bank activities (Hagendorff, 2014). This special monitoring of regulators for banks is a form of supplementary governance, for example the well-known restrictions imposed by US regulators on the executive compensation. Moreover, with regards to the banking industry, a government can also own banks and act on its own interests (Santomero, 1997). Previous studies show that state-owned banks underperform compared to 
private banks (Iannotta et al., 2007; Lin and Zhang, 2009). This is due to the fact that stateowned banks have to provide primarily funding for governmental projects that might dampen bank performance (Altunbas et al., 2001).

Investment banks focus primarily in non-interest income activities and hence they differ principally from other types of banks, such as commercial banks, that concentrate on interest income operations (Demirguc-Kunt and Huizinga, 2010). In addition, after the hit of the financial crisis of 2008, government intervention in the investment banking is particularly evident, as many US investment banks had to convert their status into Bank Holding Companies (BHCs) in order to gain access in the Federal Deposit Insurance (FDIC) support (Volcker, 2010) and other funding programs, such as the Troubled Asset Relief Program (TARP). The status of investment banks as part of BHCs implies that the main stakeholders have become other banks in the group and the government. These structural changes could lead to a rise in moral hazard of investment banks because it enables them to rely on the funds of other banking institutions that belong to the BHC (Mayer and Carlyn, 2008) and on the 'implicit government guarantee' that the access to FDIC support implies (Sironi, 2003; Gropp et al., 2006, 2013). Therefore, examining the impact of the corporate governance on the performance of investments banks is important for both bank managers and regulators. Furthermore, an advantage of our analysis is that it tests for threshold-effects of important corporate governance variables with respect to bank performance over a period that covers the financial crisis and the immediate period after. Possible changes in the percentage of banks that belong to threshold regimes would imply transformations in the structure of corporate governance mechanisms of investment banks before and after the turmoil. Therefore, this study could also shed light on the effect of corporate governance changes on investment bank performance since the period that investment banks have been converted to BHCs. 
The current banking literature focuses on various dimensions of corporate governance. Table 1 presents an overview of the recent studies that examine the impact of corporate governance on bank performance. A number of papers put emphasis on board structure (Andres and Vallelado, 2008; Tanna et al., 2011; Adams and Mehran, 2012; Pathan and Faff, 2013; Liang et al., 2013), i.e., board size, board composition and gender diversity, and its impact on bank performance. Other studies look at the effect of the executive compensation and managerial incentives on performance (Pi and Timme, 1993; Fahlenbrach and Stulz, 2011; Beltratti and Stulz, 2012; Erkens et al., 2012) and bank risk (Vallascas and Hagendorff, 2013; Berger et al., 2014). A smaller amount of studies examine the relationship between the CEO power and bank performance (Mishra and Nielsen, 2000) and risk (Pathan, 2009). Lastly, there is also empirical evidence regarding the effect of operational complexity on bank performance (Adams and Mehran, 2012). Hence, according to the corporate governance literature there are five broad study areas: board structure, executive compensation, managerial incentives, CEO power and operational complexity.

\section{[INSERT TABLE 1 ABOUT HERE]}

In terms of methodology, there are also plethora of approaches. Some of the above studies (Andres and Vallelado, 2008; Pathan and Faff, 2013; Liang et al., 2013) use a dynamic panel regression framework (two-step 'system' GMM estimator) for their analysis, while others (Fahlenbrach and Stulz, 2011; Beltratti and Stulz, 2012) employ cross-sectional type of estimations as they examine only a short period of time (2007-2008). However, employing a dynamic panel method is more relevant in the context of this study, as it accounts for endogeneity issues that arise from the examination of the relationship between corporate governance and bank performance. Additionally, the well-known persistence in bank profits (Berger et al., 2000) could be treated by the usage of the lagged dependent variable among the regressors (Athanasoglou et al., 2008). With regards to the methods employed for the 
estimation of bank performance most of the studies use accounting-based indicators (Mishra and Nielsen, 2000; Andres and Vallelado, 2008; Adams and Mehran, 2012; Aebi et al., 2012; Pathan and Faff, 2013; Liang et al., 2013), neglecting this way the importance of using a structural approach of measuring performance, i.e. the Stochastic Frontier Analysis (SFA). The SFA approach of measuring bank performance has the advantage of accommodating a full set of information from bank balance sheets, and not just a single ratio as simple accounting indicators, whilst it is based on the fundamental notion of microeconomic theory of optimising when it comes to performance. In addition, according to Hughes and Mester (2010) using SFA for measuring bank performance reveals bank managers' preferences over revenues and costs as well as their underlying risk attitude. In this paper, we opt for the SFA approach, whilst as part of a sensitivity analysis also employ accounting-based performance measures. Additionally, the majority of existing studies examines the impact of corporate governance on bank performance of commercial banks or BHCs (Mishra and Nielsen, 2000; Andres and Vallelado, 2008; Fahlenbrach and Stulz, 2011; Beltratti and Stulz, 2012; Adams and Mehran, 2012; Aebi et al., 2012; Pathan and Faff, 2013; Liang et al., 2013). However, none of these studies focuses exclusively on the examination of the underlying relationship between the corporate governance and performance of investment banks.

This paper contributes to the existing literature in several ways. It is the first study to examine the impact of corporate governance on investment bank performance during both the pre-crisis and post-crisis period. Secondly, we employ a comprehensive set of corporate governance measures that includes board structure, compensation, managerial ownership, CEO power and operational complexity. Thirdly, we use both simple accounting-based indicators and the SFA approach to proxy for bank performance, providing in that way additional evidence for the validity of our findings. Finally, for the first time we opt for a dynamic threshold model (Kremer et al., 2013) to investigate possible threshold-effects of some key corporate 
governance determinants of the investment bank performance under a period of financial distress. The main advantage of this analysis is that different regimes are identified endogenously from the underlying data generating process.

Our results show that the board size asserts a negative effect on performance consistent with the 'agency cost' hypothesis, particularly for banks with board size higher than ten members. The threshold analysis reveals that in the post-crisis period most of investment banks opt for boards of less than ten members, aiming to decrease agency conflicts endemic in large boards. We also find evidence of a negative association between operational complexity and performance. Moreover, CEO power asserts a positive effect on performance in line with the 'stewardship' hypothesis. In addition, an increase in the ownership held by the board has a negative impact on the performance of banks below an identified ownership threshold. On the other hand, for banks with board ownership above the threshold value this effect proves to be positive, indicating an alignment between shareholders' and managers' incentives.

The rest of the paper is structured as follows. Section 2 presents the hypotheses development and discusses further the related literature review. Section 3 introduces the data while Section 4 discusses the methodology. Section 5 provides the empirical findings and Section 6 concludes.

\section{RELATED LITERATURE AND HYPOTHESIS DEVELOPMENT}

\section{BOARD SIZE AND BANK PERFORMANCE}

Agency theory posits that a large board can be less efficient than a small board due to a rise in agency conflicts because of inefficient communication and cooperation costs (Jensen, 1993; Lipton and Lorsch, 1992). On the contrary, an earlier study by Pfeffer (1972) finds that board size is positively linked to the performance of large firms. The reason being that large firms have a greater need of more board members who can legitimate the company to its external environment. Andres and Vallelado (2008) show that there exists an inverted U-shaped association between the board size and bank performance for 69 commercial banks from six 
European countries over the 1995-2005 period. This indicates that an increase in the number of board members enhances the performance of banks, but when the board size becomes very large this in turn can have the adverse effect on performance due to high information asymmetries among the board members. Similarly, Pathan and Faff (2013) study the impact of the board size on the performance of US BHCs for the 1997-2011 period. They observe a negative relationship between the board size and performance as estimated by Tobin's Q, return on assets (ROA), return on equity (ROE) and pre-tax operating income (POI) ratios. On the other hand, Adams and Mehran (2012) observe the impact of the board size on the performance of 35 BHCs over the 1965-1999 periods, concluding that board size is positively related to bank performance as estimated by Tobin's Q and ROA ratio. Based on these arguments, the first hypothesis H1.A, along with the competing hypothesis H1.B, can be defined as:

H1.A (H1.B): An increase in the number of board members could have a positive (negative) effect on the performance of investment banks.

\section{BOARD COMPOSITION AND BANK PERFORMANCE}

Jensen and Meckling (1976) argue that more independent oriented boards are positively related with firm performance. Dalton et al. (1998) suggest that independent directors minimize managerial entrenchment risk through their expertise and objectivity in the decision-making process. Empirical evidence shows that an increase in the number of independent directors has a positive impact on the performance, in terms of return on invested capital and market-to-book values, for a sample of European banks (Busta, 2007). Moreover, Tanna et al. (2011) examine the impact of the board independence on the performance, as estimated by various efficiency measures, of seventeen banking institutions in the UK. They conclude that there exists a positive and significant relationship between the board independence and bank efficiency over the period 2001-2006. On the contrary, according to the 'stewardship' theory (Donaldson, 1990) there is no conflict between the interests of shareholders and managers. Under this notion a rise 
in the proportion of non-independent directors (insiders) could contribute positively to firm performance, as insiders have more experience and better firm-specific knowledge (Wiseman and Gomez-Mejia, 1997). Also, a higher level of independence may result in infertile political activity by non-independent members that could lessen the productivity of the outsiders and decrease the cooperation among the board members (Westphal, 1998, 1999). In support of this argument, Erkens et al. (2012), using a sample of 296 banks across 30 countries over the financial crisis period (2007-2008), report that board independence dampens performance as measured by buy-and-hold stock returns. Similarly, Pathan and Faff (2013) observe a negative relationship between performance, estimated by various financial indicators, and board composition for the 1997-2011 period. By contrast, Choi and Hasan (2005) find an insignificant effect of the board composition on performance, as estimated by both accounting-based indicators (ROA and ROE) and profit efficiency, for a sample of Korean banks over the 19982002 period. Following the above discussion, the second hypothesis H2.A, along with the opposing hypothesis H2.B, can be formulated as:

H2.A (H2.B): An increase in the proportion of independent directors could have a positive (negative) impact on the performance of investment banks.

\section{GENDER DIVERSITY AND BANK BERFORMANCE}

Robinson and Dechant (1997) suggest that female directors are likely to be more committed to their duties and communicate better with the other board directors. In support of the view that women are more productive at this level of hierarchy, Eagly and Carli (2003) argue that the 'glass ceiling' effect motivates females to be even more proficient in order to reach these kind of positions in a firm. The 'glass ceiling' hypothesis describes the gender discrimination in a firm. Under this hypothesis, there is misperception that women have inferior skills than men and therefore the former face additional hurdles to enter the market and hold a directorship (Martell, 1999; Baxter and Wright, 2000). Empirical evidence points out in two different 
directions with respect to the impact of gender diversity on the bank performance and risk. Pathan and Faff (2013) find that gender diversity, estimated as the percentage of female directors in the board, has a positive impact on bank performance proxied by Tobin's Q, ROA, ROE and POI ratios. On the other hand, Berger et al. (2013) document a negative relationship between an increase in the number of female board directors and bank risk for a sample of German banks over 1994-2010 periods. The reason being that females might have less experience dealing with high risks compared to males board members. Thus, the third hypothesis H3.A, along with the competing hypothesis H3.B, can be stated as:

H3.A (H3.B): An increase in the proportion of female board members could have a positive (negative) impact on the performance of investment banks.

\section{CEO POWER AND BANK PERFORMANCE}

A CEO who also chairs the board (CEO duality) or has a long term relationship with the company, i.e., CEO is the founder of the firm or has been a member of the board before becoming CEO ('internally’ hired CEO), has increased power as can influence board decisions and reduce the independency of the board of directors. According to the 'entrenchment' hypothesis, entrenchment risk occurs when managers obtain so much power and are able to use it to maximize their own utility rather than the value of shareholders (Weisbach, 1988; Finkelstein and D'Aveni, 1994). Against this view, there is theoretical background termed as the 'stewardship' theory (Donaldson, 1990; Barney, 1990). This theory suggests that a strong CEO would act as a good agent of company's assets and a firm would take advantage of the unity of direction and strong command and control that the powerful CEO would offer. In support of the 'entrenchment' hypothesis, Mishra and Nielsen (2000) find that for a sample of commercial banks the CEO who also chairs the board (CEO 'duality') has a negative impact on their performance as proxied by return on average asset (ROAA) and return on average 
equity (ROAE). On the other hand, Pathan (2009) finds that the CEO duality decreases risktaking and in turn could improve bank performance for a sample of US BHCs over the period 1997-2004. Drawing from these arguments, the fourth hypothesis H4.A, together with the opposing hypothesis H4.B, can be defined as:

H4.A (H4.B): Higher CEO power could have a positive (negative) impact on the performance of investment banks.

\section{EXECUTIVE COMPENSATION AND BANK PERFORMANCE}

Executive compensation has been a popular subject area (Barro and Barro, 1990; Zajac and Westphal, 1994; Hubbard and Palia, 1995; Crawford et al., 1995; Bedchuk et al., 2009), whilst it frequently hits news headlines worldwide. It is a subject that has been raising controversy for some time, in particular in the aftermath of the financial meltdown in 2008. Compensation is typically categorised into two forms: 1) cash that includes base salary and bonus 2) and equitybased compensation that includes stock options and restricted stock grants and constitutes a form of long-term compensation. Agency theorists argue that a long-term form of compensation better aligns managers' and shareholders' incentives (Jensen and Murphy, 1990), as long-term pay normally reward managers when they meet firms' performance goals (Baysinger and Hoskisson, 1990). Fahlenbrach and Stulz (2011) examine the impact of the executive compensation on the performance of 77 banks for the 2007-2008 period. Their results show a positive association between the equity-based compensation and performance, estimated as buy-and hold returns, during the turmoil. Another study by Vallascas and Hagendorff (2013) looks at the impact of the compensation on bank risk focusing on the cash bonus payment of CEOs. They conclude that the CEO cash bonus has a negative effect on bank default risk, implying a positive impact of the former on bank performance. Apart from the compensation of the CEO and its impact on bank performance, the compensation of top executives (top management team, TMT) has received very little empirical attention due to the 
assumption that the compensation schemes of TMT are 'isomorphic' with those of the CEO (Carpenter and Sanders, 2002). However, Finkelstein and Hambrick, (1996) and Henderson and Fredrickson (2001) argue that there is no evidence to support the convergence in the compensation of the CEO and TMT, while Hambrick (1995) shows that there is large gap among them. Therefore, when one examines the relationship between the CEO compensation and bank performance it is also important to control for the effect of the TMT compensation. Overall, the above theoretical and empirical analysis shows that the association between the CEO equity-based compensation and performance could be positive, thus the fifth hypothesis can be stated as:

H5: An increase in the CEO equity-based compensation could have a positive impact on the performance of investment banks, after controlling for the TMT compensation.

\section{OWNERSHIP AND BANK PERFORMANCE}

Following Jensen and Meckling (1976) and Eisenhardt (1989), the distinction of the ownership and managerial control leads to the misalignment between the interests of the shareholders and those of the boards. Corporate governance analysts claim generally that managers' interest are in line with shareholders' when the former have partial ownership of the company (Murphy, 1999). In support of this perception, Pi and Timme (1993) find that for banks with nonchairman CEO there is a positive relationship between ownership and performance, estimated by ROA and efficiency, for a sample of US banks over the 1987-1990 periods. Lately, the financial crisis has motivated researchers to examine the corporate governance of banking entities in terms of managers' incentives over the period of the financial crisis. However, Fahlenbrach and Stulz (2011) find that there is no statistical evidence to show that the CEO incentives were not aligned with the shareholders' interests during the period of the turmoil. Similarly, Beltratti and Stulz (2012) stress that banks with higher proportion of board ownership operate worse than banks with less board ownership for a sample of US banks over 
the 2007-2008 period. The reason being that banks with high ownership boards have been positioned in ways that managers assumed that would maximize shareholder wealth. However, this policy could potentially leave banks exposed to high risk and could have a negative effect on bank performance. Therefore, our sixth hypothesis H6.A and the competing hypothesis H6.B can be specified as:

H6.A (H6.B): An increase in the managerial ownership could have a positive (negative) impact on the performance of investment banks.

\section{OPERATIONAL COMPLEXITY AND BANK PERFORMANCE}

Operational complexity denotes the variety of activities, which are related to a firm's operations (Child, 1972). The higher the level of complexity a firm has, the more apparent becomes the need of higher expertise and knowledge specific to the environment. This implies that co-ordination problems between specialists rise and can increase correspondingly communication costs of the firm (Lawrence and Lorch, 1967). Adams and Mehran (2012) observe a negative impact of complexity on bank performance, which is consistent with the theoretical argument advanced by Lawrence and Lorch (1967). In addition, Adams and Mehran (2012) find that this negative effect turns to be positive when banks have more lead directors that sit on subsidiary boards. These directors are capable of managing effectively the bank and hence can deal with increased complexity. This also implies that banks might need more independent members in their boards, because these board members are able to improve the expertise and knowledge that banks need. However, as the director independency increases, the level of the attendance and effort of independent members on board and committee meeting decreases, resulting in the rise of free-riding problems that large banks suffer from (Jensen, 1993). The above discussion shows that the association between the operational complexity 
and performance could be negative after controlling for committee and board related variables, thus:

H7: An increase in the operational complexity could have a negative impact on the performance of investment banks, after controlling for board and committee related variables.

\section{DATA AND PRELIMINARY ANALYSIS}

\section{DATA}

Our sample consists of the major 23 listed investment banks headquartered in the US with standard industry classification (SIC) of 6211 and 6282. Our unbalanced panel dataset includes 203 observations over the period 2000-2012. The data are collected from DEF 14A proxy statements, 10-K annual reports, Bankscope and Thomson Financial's Banker.

The corporate governance data are hand collected from DEF 14A proxy statements of annual meetings found in the SECs EDGAR filings. Following previous studies (Pathan, 2009; Adams and Mehran, 2012; Pathan and Faff, 2013) governance data are measured from the date of the proxy statement. Financial information on investment banks comes from Thomson Financial Banker as well as from 10-K annual reports of SEC'S filings and Bankscope. We include only the listed investment banks as information on corporate governance data are standardised through the SEC Edgar platform. Our main inclusion criterion is that our sample is consisted by financial institutions that their main source of income includes fees, commission and trading revenues, reflecting in that way investment banks' distinctive operational nature.

\section{[INSERT TABLE 2 ABOUT HERE]}

Our corporate governance data comprise five general dimensions; board structure, CEO-power, compensation of the CEO and TMT, ownership of CEO and board members and operational complexity measures. In particular, we account for three board characteristics, namely board 
size, board composition and gender diversity. The first two variables have been used extensively in the corporate governance literature (Staikouras et al., 2007; Busta, 2007; Adams and Mehran, 2008; Andres and Vallelado, 2008; Tanna et al., 2011). Board size is the number of members that constitutes the board, while board composition refers to the proportion of independent members in the board. Gender diversity is the percentage of females in the boardroom (Shrader et al., 1997; Campel and Minguez-Vera, 2008; Francoeur et al., 2008).

We employ two measures of CEO power; CEO duality and 'internally' hired CEO. CEO duality is a dummy that takes the value of 1 if the CEO chairs the board as well, and 0 otherwise (Rechner and Dalton, 1989, 1991; Donaldson and Davis, 1991; Daily and Dalton, 1992, 1993; Daily, 1995; Boyd, 1995; Baliga et al., 1996; Dalton et al., 1998; Ballinger and Marcel, 2010). CEO 'internally' hired is a dummy variable that takes the value of one 1 if the CEO is either the founder or has been member of the board before being moved to the CEO position, while otherwise it takes the value of zero (Adams et al., 2005; Pathan, 2009; Fahlenbrach 2009). As additional CEO characteristics, we control for the CEO tenure and the CEO age. The CEO tenure is estimated by the number of years that the CEO has served in the same position (Mishra and Nielsen, 2000; Cornett et al., 2008; Pathan and Faff, 2013). Finally, the CEO age stands for the age that the CEO has (Mishra and Nielsen, 2000; Cornett et al., 2008).

In order to examine the impact of the ownership on bank performance we use the number of shares hold by the CEO and TMT as the percentage of total outstanding number of bank's shares (Beltratti and Stulz, 2012; Aebi et al., 2012). We also control for the cash short-term incentives by employing the ratio of bonus over total cash compensation of the CEO and the TMT (Fahlenbrach and Stulz, 2011). Moreover, we examine the impact of cash and equity compensation of CEO and TMT on investment bank performance. The natural logarithm of cash-based compensation includes the base salary and bonus, while the natural logarithm of equity-based compensation includes restricted stock and stock options. Decomposition of the 
compensation has been used in a number of studies that investigate differences on the impact of cash-based and equity-based compensation on performance (Baysinger and Hoskisson, 1990; Frye, 2004; Carpenter and Sanders, 2002). We also examine the impact of the operational complexity on bank performance. Operational complexity is proxied by the number of different business segments (Booth and Deli, 1999; Bushman et al., 2004; Linck et al., 2007) and subsidiaries (Adams and Mehran, 2012). Moreover, we control for the total outstanding number of board committees (Vafeas, 1999), the fees paid to the board committees and the number of audit committee meetings (Xie et al., 2003; Goodwin-Stewart and Kent, 2006).

Turning to the bank-specific control variables that are not related to corporate governance, we opt for the ratio of equity to total assets as a proxy of leverage (Berger and Bonaccorsi di Patti, 2006). We also use the ratio of other earning assets over total assets in line with Beltratti and Stulz (2012), so as to capture the different nature of investment banks centered on equity issuance and underwriting activities. We further employ the ratio of investment banking fees over total assets as the non-interest income reflects the main source of income of investment banks (Radic et al., 2012). Lastly, we control for the insolvency risk as estimated by the z-score introduced by Boyd's and Graham (1986). ${ }^{\text {ii }}$

In addition, in our analysis we account for the regulatory mandates with the introduction of the Sarbanes-Oxley Act (SOX) in 2002 as a dummy, which takes the value of 0 if year is 20002001 and the value of 1 otherwise consistent with Pathan and Faff (2009). ${ }^{\text {iii }}$ We also impose a crisis dummy, which takes the value of 1 if year is 2007-2010 and zero otherwise in order to account for the financial crisis period (Pathan and Faff, 2009; De Jonghe et al., 2012). Finally, in order to capture the market risk we use the Volatility Implied Index indicator (VIX). ${ }^{\text {iv }}$ This financial indicator suggests that higher levels of VIX reflect higher degrees of financial turmoil in the US (Whaley, 2000).

DESCRIPTIVE STATISTICS 
The descriptive statistics for the corporate governance variables are provided in Table 2.

\section{[INSERT TABLE 3 ABOUT HERE]}

The sample mean of board size in Panel A of Table 3 is 8.30, which is similar to that of 10 in Coles et al. (2008) and 9 in Francis et al. (2012). Moreover, our sample mean of gender diversity of 0.11 is comparable to that of 0.076 in Pathan and Faff (2013). Turning to CEO characteristics, the sample mean of CEO duality is 0.72 , while that of CEO 'internally' hired is 0.65 which is similar to that of 0.58 in Pathan and Skully (2010). The CEO age sample mean is 55.35 (years), which is comparable to that of 56.26 in Cornett et al. (2009). Also, the mean tenure of the CEO is 7.74 (years) and is similar to that of 8.85 in Pathan and Skully (2010). With regards to the ownership, the sample mean of board ownership is $12.27 \%$, which is comparable to that of $10.25 \%$ in Pathan and Skully (2010) and to that of $9.63 \%$ in Andershon and Fraser (2000). Our CEO ownership sample mean is $6.08 \%$ which is consistent to that reported $(4.41 \%)$ by Pathan and Skully (2010). The sample mean of the number of board committees is 3.32, and is in line to that found (4.9) by Adams and Mehran (2003). Lastly, the sample mean of the total outstanding number of business segment is 3.04, which is also comparable to that of 2.6 in Coles et al. (2008).

In Panel B of Table 3 we present some descriptive statistics of control variables, namely E/TA, FEES, EARN, Z-SCORE and the VIX financial indicator. The sample mean of return on average equity, ROAE, in Panel C of Table 3 is $8.02 \%$, which is similar to the sample mean of 9.92\% in Pathan and Faff (2013). Moreover, our mean efficiency score for the US investment banks is 0.65 , which is similar to the sample mean of 0.66 in Radic et al. (2012).

Panel D shows an upward trend in the average percentage of independent members of the board over time, with a notable increase from $60 \%$ in 2003 to $69 \%$ in 2006 . This increase is attributed 
to the independent board requirements imposed by SOX. Lastly, we also observe that the mean of the CEO ownership was sharply reduced from $6.39 \%$ in 2007 to $2.84 \%$ in 2008 .

\section{METHODOLOGY}

\section{BANK PERFORMANCE MEASURES}

There are two broad approaches to evaluate bank performance; 1) the structural method is based on the economics of profit maximization or cost minimization under which bank performance is estimated as a function (profit or cost) by employing either a parametric (Stochastic Frontier Analysis-SFA) or a non-parametric methodology (Data Envelopment Analysis-DEA). This approach involves the estimation of an efficient frontier, where bestpractice banks operate, and the measurement of the distance between the point that less efficient banks operate and the efficiency frontier. 2) the non-structural method refers on realized bank performance measured by a number of financial indicators. These indicators are the accounting-based performance ratios such as re return on average assets (ROAA), return on average equity (ROAE) and pre-tax operating income (POI) as a percentage of the average total assets (Chen, 2009; Mensah et al., 2012; Hughes and Mester, 2013). In addition, non-structural measures involve indicators that are based on the market value of the bank, such as the Tobin's q, which have been used in the banking literature to gauge the performance of banks (Adams and Mehran, 2008; Peni and Vähämaa, 2012; Pathan and Faff, 2013). ${ }^{v}$

There are numerous empirical studies (Hasan and Marton, 2003; Bonin et al., 2005; Pasiouras et al., 2009; Lozano-Vivas and Pasiouras, 2010; Casu and Girardone, 2010; Sun and Chang, 2011; Barth et al., 2013) that employ structural methods (SFA or DEA) to evaluate bank performance, while others use accounting-based financial ratios (Klapper and Love, 2004; Athanasoglou et al., 2008; Lin and Zhang, 2009; Aebi et al., 2012). In our study, we employ the SFA approach as estimated by a profit function and three accounting-based ratios, namely ROAA, ROAE and POI. The reason that we employ a profit function, instead of a cost-function, 
is because corporate governance can be seen as a set of internal mechanisms aiming to maximize the value of a bank (Denis et al., 2001). Besides, investment banks are revenuemotivated institutions and hence the profit function is appropriate when one estimates the efficiency of these financial institutions consistent with Radic et al. (2012). In addition, 'profit maximization is superior to cost minimization for most purposes because it is the more accepted economic goal of firm's owners' as argued by Berger and Mester (1999, p. 3).

By employing both the profit function and accounting ratios we rely on two different approaches, strengthening in that way the robustness of our results. One might argue that because SFA's efficiency scores and accounting-based performance indicators might be highly correlated that in turn would lead both estimation approaches to give similar results. The SFA approach of measuring bank performance has the advantage of accommodating a full set of information from bank balance sheets, and not just a single ratio as in accounting indicators, whilst it is based on the fundamental notion of microeconomic theory of optimising when it comes to performance. In addition, according to Hughes and Mester (2010) using SFA for measuring bank performance reveals bank managers' decisions, regarding expected revenues, costs and the underlying risk. Furthermore, Beccalli (2007) argue that accounting-based ratios do not count for changes in the production process, input and output mix. Therefore, these two performance measures (SFA and accounting-based indicators) might reflect different type of information and thus the correlation between them might be fairly low. Indeed, our findings show that the correlation between profit efficiency scores (EFF) and the three accounting based ratios (ROAA, ROAE and POI) is positive but is relatively low (see Table 4), as in Bauer et al. (1998) and Koetter (2006).

[INSERT TABLE 4 ABOUT HERE] 
We opt for the SFA, as introduced by Aigner et al. (1977), to estimate profit efficiency scores. The advantage of this parametric methodology relative to the non-parametric (DEA) approach is that both the random error and inefficiency are combined in a composite error term (Berger and Humphrey, 1997). To do so we use a fixed-effect specification where efficiency scores are independently and identically distributed (Greene, 2002).

In particular we use the following specification for the profit frontier:

$$
T P_{i t}=f\left(P_{i t}, Y_{i t}, N_{i t}\right)+v_{i t}+u_{i t}
$$

where $T P_{i t}$ is pre-tax profits for bank i in year t. ${ }^{\mathrm{vi}} P_{i t}$ is a vector of input prices, $Y_{i t}$ is a vector of outputs, $N_{i t}$ is a fixed net-put. The term $v_{i t}$ stands for the error term, while $u_{i t}$ denotes bank inefficiency.

Moreover the translog profit function, opted in the paper, takes the form:

$$
\begin{gathered}
\ln P_{i, t}=\alpha_{0}+\sum_{i} \alpha_{i} \ln P_{i, t}+\sum_{i} \beta_{i} \ln Y_{i, t}+1 / 2 \sum_{i} \sum_{j} \alpha_{i j} \ln P_{i, t} \ln P_{j, t}+1 / 2 \sum_{i} \sum_{j} \beta_{i j} \ln Y_{i, t} \ln Y_{j, t}+ \\
+\sum_{i} \sum_{j} \delta_{i j} \ln P_{i, t} \ln Y_{j, t}+\sum_{i} \zeta_{i} \ln N_{i, t}+1 / 2 \sum_{i} \sum_{j} \zeta_{i j} \ln N_{i, t} \ln N_{j, t}+1 / 2 \sum_{i} \sum_{j} \theta_{i j} \ln P_{i, t} \ln N_{j, t}+ \\
+\sum_{i} \sum_{j} \kappa_{i j} \ln Y_{i, t} \ln N_{j, t}+\mu_{1} t+1 / 2 \mu_{2} t^{2}+\sum_{i} v_{i} \operatorname{tln} P_{i, t}+\sum_{i} \xi_{i} \ln Y_{i, t}+\sum_{i} \rho_{i} \ln N_{i, t}+ \\
+u_{i, t} \pm v_{i, t}
\end{gathered}
$$

Ordinary linear homogeneity and symmetry limitations are employed. We estimate equation (2) with a maximum likelihood method parameterized based on the variance parameters: vii

$$
\begin{aligned}
\sigma_{\varepsilon}^{2} & =\sigma_{u}^{2}+\sigma_{v}^{2} \\
\text { and } \beta & =\sigma_{u}^{2} / \sigma_{\varepsilon}^{2}
\end{aligned}
$$

Following Sealey and Lindley (1977) we employ the 'intermediation' approach in order to define bank inputs and outputs. This approach assumes that banks use labour and capital in order to collect funds and transform them into loans and other earning assets. We follow this approach that is used in numerous previous studies (Altunbas et al., 2001; Isik and Hasan, 2002, 
2003; Fries and Taci, 2005; Casu and Girardone, 2006; Gaganis and Pasiouras; 2013) to estimate efficiency and which is also employed by Radic et al. (2012) who are the only ones to this date to examine the performance of investment banks in terms of profit efficiency. Hence, with regards to the inputs used we also employ the price of labour and physical capital, which is the norm in the banking literature (Berger and Mester, 1997). The price of labour is measured as the ratio of personnel expenses to total assets, while the price of physical capital is measured as the ratio of operating expenses to fixed assets. The selection of outputs for investment banks should reflect their operational nature and hence we could not use loans, because this is the standard output used for the efficiency estimation of commercial banks. Investment banks differ fundamentally from commercial banks, as the former engage primarily in non-interest operations and hence they lack the deposit base that conventional banks have. Therefore, for the selection of the outputs we follow Radic et al. (2012) and employ two outputs that are associated closely to the operational nature of investment banks; 1) we use the sum of other earning assets that include trading securities, derivatives, treasury bills and bonds 2) and the total level of investment banking fees that include net commission, fees and trading gains and comprises the main source of income of investment banks. Lastly, as fixed netput, we employ the total level of fixed assets that is also standard in the literature related to efficiency estimation (Berger and Mester, 1997; Berger and Mester, 2003).

\section{SECOND STAGE REGRESSIONS}

\section{DYNAMIC PANEL ANALYSIS}

For the second-stage regressions, we opt for the two-step 'system' GMM estimator (Arrelano and Bover, 1995; Blundell and Bond, 1998), as used in previous papers to examine the relationship between corporate governance and bank performance (Andres and Vallelado, 2008; Liang et al., 2013; Pathan and Faff, 2013), aiming to account for endogeneity issues. ${ }^{\text {viii }}$ In 
addition to this, the documented persistence in bank profits (Berger et al., 2000; Goddard et al., 2004) is treated by the inclusion of the lagged dependent variable among the regressors, according to Athanasoglou et al. (2008). Therefore, the use of the dynamic panel two-step 'system' GMM estimator is relevant to the context of this study. The two-step estimates of standard errors are likely to be downward biased (Blundell and Bond, 1998) and thus we follow a finite sample correction introduced by Windmeijer (2005). The estimates are also tested via Hansen's diagnostic test for instrument validity and the test for second-order autocorrelation of error terms introduced by Arellano and Bond (1991).

The dynamic panel model that we use takes the following form:

$(\text { Perform })_{i, t}=\left[a_{0}+\varphi(\text { Perform })_{i, t-1}+a_{1}(\text { PSOX })_{t}+a_{2}(C R S)_{t}+\beta_{j} \sum_{j=1}^{n}(\right.$ Corpor Govern $\left.)_{i, t}+\gamma_{j} \sum_{j=1}^{1}(\text { Control })_{i, t}+e_{i, t}\right]$

where $\mathrm{i}$ signifies individual investment bank $(\mathrm{i}=1,2, \ldots, 23)$ and $\mathrm{t}$ is the period that we cover $(\mathrm{t}$ $=2000,2001, \ldots, 2012) . \alpha, \beta, \gamma$ are parameters to be estimated. $(\text { Perform })_{i, t}$ is the dependent variable and stands for the performance of investment banks estimated by ROAA, ROAE, POI and EFF, while (Perform) $)_{i, t-1}$ stands for the lagged performance dependent variable. $(P S O X)_{\mathrm{t}}$ is a dummy variable that takes the value of 0 in the post SOX period (2000-2001) and 1 otherwise. $(C R S)_{t}$ is a crisis dummy that takes the value of 1 if year is 2007-2010, and 0 otherwise. (Corpor-Govern) $)_{i, t}$ consists of five different dimensions of corporate governance variables: 1) board size, board composition and gender diversity 2) CEO 'internally' hired, CEO duality, CEO age and CEO tenure 3) cash-based and equity-based compensation of the TMT and CEO 4) CEO/board ownership and CEO/TMT bonus as a percentage of total cash compensation and 5) number of business segments, number of subsidiaries, number of board committees, fees paid for the attendance of members in board committees and number 
of audit committee meetings. (Control $)_{i, t}$ comprises of a number of bank-specific and country-level control variables while $e_{i, t}$ denotes the error term. ${ }^{\text {ix }}$

\section{THRESHOLD DYNAMIC PANEL ANALYSIS}

As a further step, we employ the dynamic panel threshold methodology (Kremer et al., 2013) to identify possible threshold-effects in important corporate governance determinants of the performance of investment banks. ${ }^{\mathrm{x}}$ The main advantage of this econometric technique is that identifies threshold values of key corporate governance variables and could observe any change on the impact of these threshold variables on bank performance under the examined period. This is important particularly as our study covers the period of financial crisis where major changes in the number of banks that belong to each threshold regime might be identified, suggesting important changes in the underlying structure of corporate governance mechanism of investment banks before and after the turmoil. Note that we use this methodology for two of the corporate governance variables found, in the initial dynamic panel regressions, to be negatively associated to the performance of investment banks. These are the board size and the board ownership.

Therefore our equation takes the following specification:

$\operatorname{perform}_{i t}=\mu+\lambda_{1} m_{i t} I\left(q_{i t} \leq \gamma\right)+\delta_{1} I\left(q_{i t} \leq \gamma\right)+\lambda_{2} m_{i t} I\left(q_{i t}>\gamma\right)+\varepsilon_{i t}$

where perform it $_{\text {is }}$ the dependent variable (ROAE) and $\mu$ is the bank-specific fixed effect parameter. The two reverse regression slopes are $\lambda_{1}$ and $\lambda_{2}$ and are defined based on the assumption that there exist two regimes. $q_{i t}$ stands for the threshold variable (board size and board ownership), $\gamma$ is the threshold value that splits the observations into two regimes: 1 ) above the threshold value (high regime), and 2) below the threshold value (low regime). $\varepsilon_{i t}$ stands for the residual. $I$ is the indicator term that signifies the regime specified by the threshold variable $\mathrm{q}_{i t}$ and the threshold value $\gamma$. As in Kremer et al. (2013), we use $m_{i t}$ as a vector of 
independent variables. ${ }^{\text {xi }}$ Moreover, Kremer et al. (2013) extends the Hansen's (1999) model by including the regime dependent intercept, $\delta_{1}$. Bick (2007) suggests that ignoring the regime intercepts would cause biased estimation of the threshold value and the scale of the regimes' coefficients. $^{\text {xii }}$

\section{DISCUSSION}

\section{DYNAMIC PANEL ANALYSIS}

Tables 5,6 and 7 present the results of the dynamic panel analysis. The appropriateness of the two-step 'system' GMM estimator is held by the significant lagged performance variable in all the corresponding models of Tables 5,6 and 7. Moreover, regarding basic diagnostics the tests $(\mathrm{AR}(2))$ for second-order autocorrelation in second differences and the Hansen J-statistics of over-identifying restrictions are insignificant (see Tables 5,6 and 7).

\section{[INSERT TABLE 5 ABOUT HERE]}

With regards to the board size, we find a strong negative impact of the board size on bank performance. The result remains robust at the 1\% level (Table 5, Models 2 and 3) and at the 10\% (Table 5, Models 4 and 4) level of significance. This finding supports the 'agency cost' hypothesis by Jensen and Meckling (1976), suggesting that an increase in the members of the board could result in higher information asymmetry and communication costs. We also find that the CEO duality has a positive impact on bank performance at the 5\% (Table 5, Model 5) and the $10 \%$ significance level (Table 5, Model 8), consistent with the 'stewardship' hypothesis (Donaldson, 1990; Barney, 1990). Under this hypothesis, the CEO who chairs the board would act as a good agent of the firm and would offer unity of direction and strong control, resulting in the improvement of performance. Our finding is consistent with numerous of previous studies (Donaldson and Davis, 1991; Boyd, 1995; He and Wang, 2009). Although there is 
robust evidence to support that the CEO duality has a positive impact on bank performance, there is no empirical study to examine the relationship between the 'internally' hired CEO and bank performance. Our results also lend support to the 'stewardship' hypothesis as there exists a positive relationship between the 'internally' hired CEO and bank performance (at the $1 \%$ level of significance, Table 5, Model 6; at the 5\% level of significance, Table 5, Model 5 and 7).

\section{[INSERT TABLE 6 ABOUT HERE]}

Concerning the impact of the CEO and TMT compensation on performance, the results show some variation depending on the different kinds of compensation, i.e., cash-based or equitybased compensation. Specifically, we find a negative impact of the cash-based compensation of TMT on bank performance at the $10 \%$ level of significance (Table 6, Model 1 and 2), while there exists a positive impact of the equity-based compensation of TMT on bank performance at the $1 \%$ level of significance (Table 6 , Model 2). These findings are not surprising, since cash-based compensation does not create sufficient incentives to executives to increase corporate value, while equity-based compensation constitutes a form of long-term pay and could align better incentives between executives and shareholders (Jensen and Murphy, 1998). Regarding the CEO compensation, we find that the CEO cash-based compensation asserts a positive effect on investment bank performance at the $1 \%$ level of significance (Table 8 , Model 1 and 3), as in the previous studies of Harris and Raviv (1979) and Grossman and Hart (1983). Similarly, we find that the CEO equity-based compensation has a positive impact on bank performance. The result remains robust at the 5\% (Table 6, Model 1 and 2) and 10\% (Table 6, Model 4) significance level.

Board ownership asserts a negative impact on bank performance at the 1\% (Table 6, Model 5 and 6) and 5\% (Table 6, Model 7) significance level. This finding is consistent with earlier 
studies (Laeven and Levine, 2009; Beltratti and Stulz, 2012) suggesting that banks with boards of higher bank ownership perform worse compared to banks with lower board ownership. This is because board members of high bank ownership position banks in a way that maximize shareholder value. This behaviour of board members can worsen the performance as banks are exposed to high risk. On the other hand, the CEO ownership has a positive impact on performance at the 5\% (Table 6, Model 5) and 10\% (Table 6, Model 7 and 8) significance level. Our finding supports the idea that the partial ownership of the CEO reduces the agency costs and aligns better shareholders' and managers' incentives, resulting in a positive impact on bank performance (Murphy, 1999). Also, we find evidence of a positive impact of the CEO and TMT bonus as a percentage of total cash compensation on bank performance. This result is comparable with that of Fahlenbrach and Stulz (2011) as they find that banks that pay higher cash bonuses as a proportion of total compensation to their executives perform better than those that pay lower level of bonuses over total compensation over the crisis period.

\section{[INSERT TABLE 7 ABOUT HERE]}

In addition, the dynamic panel estimations reveal a negative impact of the operational complexity on bank performance. We find that an increase in both the number of different business segments and the total outstanding number of subsidiaries reduces bank performance. The results are robust at the 1\% (Table 7, Model 2 and 3) and 5\% (Table 7, Model 2) level of significance. These findings imply that banks that are characterized by higher operational complexity operate less efficiently compared to banks of lower operational complexity. This is so as in banks of high business complexity, co-ordination problems between specialists rise, and this can increase correspondingly communication costs of the bank (Lawrence and Lorch, 1967). Also, we find evidence that an increase in the number of committees reduces bank performance at the 10\% (Table 7, Model 1, 2 and 4) and 5\% (Table 7, Model 3) significance level. This implies that although an increase in the amount of task's delegation from board to 
committees might reduce the time and effort that boards devote as a group of directors, but could rise the amount of the resources that the board divert for the supervision of the increased number of outstanding committees (Vafeas, 1999). Lastly, we also find that fees paid to board committees are associated negatively to performance at the $1 \%$ significance level (Table 7 , Model 2 and 3).

In terms of the effect of the rest of the bank-specific control variables, we find that an increase in leverage (decrease in the equity over total assets ratio) has a positive impact on performance. The reason being that higher levels of leverage mitigate the agency costs, between the outside equity and managers, that arise from the choice of investment (Myers, 1977), the risk of bank liquidation (Harris and Raviv, 1990) and the undertaken risk (Jensen and Meckling, 1976). We also report a positive impact of investment banking fees over total assets ratio on bank performance. Fees constitute the main source of income for investment banks, hence an increase in fee-income improves bank profitability (Beccalli, 2007; Micco et al., 2007; Lin and Zhang, 2009). Also, the bank's insolvency risk, as proxied by the z-score, asserts a negative impact on bank performance consistent with the 'bad luck' hypothesis advanced by Berger and De-Young (1997). ${ }^{\text {xiii }}$ The dynamic panel analysis provides also evidence of the negative and significant impact of other earning assets over total assets ratio on performance. The negative coefficient suggests that activities such as trading securities may induce high risk of bank losses (Demirguc-Kunt and Huizinga, 2010).

We also find that the VIX indicator has a negative effect on bank performance, signifying that increases of market volatility dampen bank performance consistent with previous studies (Bourke 1989; Miller and Noulas, 1997). Also, as it is expected, there is a negative impact of the financial crisis dummy on bank performance (Pathan and Faff, 2013). Lastly, we find a strong negative impact of the PSOX period on performance, indicating that high board 
independency reduces the level of meeting attendance of the independent board members (Adams and Ferreira, 2007) that in turn increases free-riding problems (Jensen, 1993).

\section{THRESHOLD DYNAMIC PANEL ANALYSIS}

In this section, we opt for the dynamic panel threshold methodology (Kremer et al., 2013) and investigate the presence of possible threshold-effects of important corporate governance variables with respect to investment bank performance. We employ this econometric technique for two of the key variables of our previous analysis (5.1). These are the board size and board ownership that we find them to be associated negatively with investment bank performance.

A study by Yemack et al. (1996) shows that there is a trade-off between advantages and disadvantages of large boards. On the one hand, banks with large boards increase the monitoring and expertise to deal with problems of the specific-bank environment. On the other hand, large boards decrease the control and the effective communication between board members. Based on these arguments, we believe that is essential to investigate possible threshold-effects of the board size impact on investment bank performance. In addition, agency theory argues that an increase in the board ownership better aligns incentives between managers and shareholders (Jensen and Meckling, 1976; Eisenhardt, 1989; Murphy, 1999). Therefore, boards that hold higher ownership are more likely to take decisions to increase the corporate value. However, our findings in the dynamic panel estimations (5.1) indicate that an increase in the board ownership decreases bank performance, as in Beltrazzi and Stulz (2011). To this end, the threshold analysis enables to investigate, if and at which level, the board ownership asserts a positive impact on investment bank performance.

\section{[INSERT TABLE 8 ABOUT HERE]}

Our analysis finds a threshold value of the board size around ten members. ${ }^{\text {xiv }}$ This threshold value splits the sample into two regimes. The low regime with banks that have board size lower 
than ten members and the high regime with banks of more than ten members in their boards. The results indicate that there is a highly negative impact at the $1 \%$ level of the board size on investment bank performance for the high regime banks, as $\lambda_{2}=-1.3778$ (see Table 8 ). This finding is consistent with the 'agency cost' hypothesis by Jensen and Meckling (1976). Moreover, the threshold value indicates that the board size of investment banks should be less than ten members, which is similar to the argument of Lipton and Lorsch (1992) who suggest the restraining of the membership of boards to ten people, with a desired size of eight or nine members. Regarding the impact of the board size on bank performance for the low regime banks, we still find a negative coefficient but the result is not statistically significant.

\section{[INSERT TABLE 9 ABOUT HERE]}

Moreover, Table 9 shows that the percentage of banks with large boards constantly increases and reaches the highest level (53\%) in 2007. This implies that the majority of the US investment banks underperformed with an increase in board size above the threshold value of 10 board members. After the burst of the financial crisis, we observe a sharp decrease (from 53\% to 27\%) in the proportion of investment banks that had large boards, suggesting that these financial institutions opted to scale down agency costs caused by large boards during the period of the turmoil.

\section{[INSERT TABLE 10 ABOUT HERE]}

Regarding the board ownership threshold analysis, we find a threshold value of $8.54 \%$ (see Table 10). This value splits the sample into investment banks with boards that hold higher ownership (high regime) and those with boards that hold lower ownership (low regime). We find that for banks in the low regime, an increase in the board ownership has a negative impact on performance at the $1 \%$ level of significance $\left(\lambda_{1}=-0.026\right)$. This result is similar to that in the previous section (5.1). However, it further reveals that the negative impact of board ownership 
refers explicitly to banks that have lower levels of board ownership, that is below the threshold value. By contrast, turning to the high regime, which denotes banks of board ownership above the threshold value, we find that there is a positive relationship between the board ownership and performance at the $5 \%$ level of significance $\left(\lambda_{2}=0.116\right)$. The result is confirmed by the agency theory (Jensen and Meckling, 1976; Eisenhardt,1989) and a number of previous studies that indicate a positive impact of the managerial ownership on performance (Kosnik, 1990; Malatesta et al., 1988; Pi and Timme, 1993).

\section{[INSERT TABLE 11 ABOUT HERE]}

Lastly, Table 11 shows that there is a constant increase over time in the percentage of banks that belong to the low regime, which includes banks with boards that hold lower levels of ownership (below the threshold value). In the 2005-2007 period, we also observe that the majority of investment banks is classified in the high regime, indicating that during the financial crisis period investment banks opted for higher level of board ownership (above the threshold value).

\section{CONCLUSION}

In this paper we investigate the impact of corporate governance on the performance of the US investment banks for the 2000-2012 period. We find that there is a negative relationship between the board size and performance. The threshold analysis reveals that this negative impact is enhanced when board size increases above the critical value of around ten board members. This implies that above a threshold value the rising costs of monitoring and communication deteriorates the performance of investment banks, consistent with the 'agency cost' hypothesis (Jensen, 1993). Adams and Mehran (2008) and Andres and Vallelado (2008) show that the impact of the board size on the performance of commercial banks is positive. Hence, investment banks appear to react differently compare to other type of banks with respect 
to the effect of the board size on performance. Threshold analysis also reveals that most of investment banks scaled down the board size, aiming to reduce agency conflicts that banks with large boards suffer from, since the crisis of 2007. Also, we find evidence that the CEO power exerts a positive impact on bank performance consistent with the 'stewardship' hypothesis (Donaldson, 1990; Barney, 1990). This indicates that investment banks perform better when the CEO chairs the board or has a long-term relationship with the bank. Thus, investment banks could benefit from the unity of control that the powerful CEO would offer. Our results shed new light and provide an alternative view to Mishra and Nielsen (2000) who argue that the CEO power have a negative impact on the performance of commercial banks. With regards to the ownership held by the board we find, similarly to Beltratti and Stulz (2012), that it has a negative impact on performance. This effect is present predominantly in banks with board ownership below a threshold value. By contrast, the impact of board ownership on investment bank performance turns to positive above a threshold value. Additionally, we find evidence of a negative association between the operational complexity and bank performance.

Our results, also in the light of the financial crisis, are of importance for both policy makers and market participants. In response to the severe financial crisis, regulators in the US passed the Dodd-Frank Act (2010), a major financial reform that has a significant impact on bank corporate governance along with other aspects of the financial markets. The transformation of investment banks into BHCs and their subsequent access into the Federal Deposit Insurance (FDIC) support (Volcker, 2010) and other subsidy programs, such as the Troubled Asset Relief Program (TARP), could lead to a rise in moral hazard problems for investment banks. Therefore, policy makers should ensure that the corporate governance of investment banks is geared towards structures that are beneficial to performance of these institutions. To this end, the identification of threshold-effects in this study could be of assistance to future regulatory mandates. Regulators could look for example at the empirical evidence whereby investment 
bank performance declines with board's size more than ten members, while enhances with boards' ownership above a threshold value.

\section{References}

Acharya, V. and M. Richardson. 2009.“Causes of the financial crisis.” Critical Review 21:2-3: 195-210.

Adams, R. and H. Mehran. 2003."Is corporate governance different for bank holding companies?.” Economic Policy Review 9:1: 123-142.

Adams, R. and D. Ferreira. 2007.“A theory of friendly boards.” The Journal of Finance 62:1: 217-250.

Adams, R. and H. Mehran. 2012."Bank board structure and performance: Evidence for large bank holding companies." Journal of Financial Intermediation 21:2: 243-267. 
Adams, R., H. Almeida, and D. Ferreira. 2005."Powerful CEOs and their impact on corporate performance.” Review of Financial Studies 18:4:1403-1432.

Adams, R. and H. Mehran. 2008.“Corporate performance, board structure, and their determinants in the banking industry." Unpublished paper, Federal Reserve.

Adrian, T. and H. Shin. 2010.“Liquidity and Leverage.” Journal of Financial Intermediation $19: 3: 418-437$.

Aebi, V., G. Sabato, and M. Schmid. 2012."Risk management, corporate governance, and bank performance in the financial crisis." Journal of Banking and Finance 36:12: 3213-3226.

Aigner, D., C. Lovell, and P. Schmidt. 1977."Formulation and estimation of stochastic frontier production function models." Journal of Econometrics 6:1: 21-37.

Altunbaş, Y., E. Gardener, P. Molyneux, and B. Moore. 2001."Efficiency in European banking." European Economic Review 45:10:1931-1955.

Anderson, R. and D. Fraser. 2000."Corporate control, bank risk taking, and the health of the banking industry." Journal of Banking and Finance 24:8:1383-1398.

Andres, P. and E. Vallelado. 2008.“Corporate governance in banking: The role of the board of directors.” Journal of Banking and Finance 32:12: 2570-2580.

Arellano, M. and S. Bond. 1991."Some tests of specification for panel data: Monte Carlo evidence and an application to employment equations." The Review of Economic Studies 58:2: 277-297.

Arellano, M. and O. Bover. 1995.“Another look at the instrumental variable estimation of error-components models." Journal of Econometrics 68:1: 29-51.

Baliga, B., R. Moyer, and R. Rao. 1996.“CEO duality and firm performance: what's the fuss?.” Strategic Management Journal 17:1: 41-53.

Ballinger, G. and J. Marcel. 2010.“The use of an interim CEO during succession episodes and firm performance.” Strategic Management Journal 31:3: 262-283. 
Barney, J. 1991."Firm resources and sustained competitive advantage." Journal of Management 17:1: 99-120.

Barro, J. and R. Barro. 1990.“Pay, performance, and turnover of bank CEOs.” Unpublished paper, National Bureau of Economic Research .

Barth, J., C. Lin, Y. Ma, J. Seade, and F. Song. 2013. "Do bank regulation, supervision and monitoring enhance or impede bank efficiency?.” Journal of Banking and Finance 37:8: 28792892.

Bauer, P., A. Berger, G. Ferrier, and D. Humphrey. 1998."Consistency conditions for regulatory analysis of financial institutions: a comparison of frontier efficiency methods." Journal of Economics and Business 50:2: 85-114.

Baxter, J. and E. Wright. 2000.“The glass ceiling hypothesis a comparative study of the United States, Sweden, and Australia." Gender and Society 14:2: 275-294.

Baysinger, B. and R. Hoskisson. 1990.“The composition of boards of directors and strategic control: Effects on corporate strategy." Academy of Management Review 15:1: 72-87.

Bebchuk, L. and J. Fried. 2003.“Executive compensation as an agency problem.” Unpublished paper, National Bureau of Economic Research.

Bebchuk, L., A. Cohen, and A. Ferrell. 2009."What matters in corporate governance?.” Review of Financial Studies 22:2: 783-827.

Beccalli, E. 2007."Does IT investment improve bank performance? Evidence from Europe.” Journal of Banking and Finance 31:7: 2205-2230.

Beltratti, A. and R. Stulz. 2012."The credit crisis around the globe: Why did some banks perform better?." Journal of Financial Economics 105:1: 1-17.

Berger, A. and E. Bonaccorsi di Patti. 2006.“Capital structure and firm performance: A new approach to testing agency theory and an application to the banking industry." Journal of Banking and Finance 30:4: 1065-1102. 
Berger, A. and R. DeYoung. 1997."Problem loans and cost efficiency in commercial banks." Journal of Banking and Finance 21:6: 849-870.

Berger, A. and D. Humphrey. 1997.“Efficiency of financial institutions: International survey and directions for future research.” European Journal of Operational Research 98:2: 175-212. Berger, A. and L. Mester. 1997."Inside the black box: What explains differences in the efficiencies of financial institutions?." Journal of Banking and Finance 21:7: 895-947.

Berger, A. and L. Mester. 1999."What explains the dramatic changes in cost and profit performance of the US banking industry?." Unpublished paper, Federal Reserve.

Berger, A. and L. Mester. 2003."Explaining the dramatic changes in performance of US banks: technological change, deregulation, and dynamic changes in competition." Journal of Financial Intermediation 12:1: 57-95.

Berger, A., S. Bonime, D. Covitz, and D. Hancock. 2000."Why are bank profits so persistent? The roles of product market competition, informational opacity, and regional/macroeconomic shocks.” Journal of Banking and Finance 24:7: 1203-1235.

Berger, A., T. Kick, and K. Schaeck. 2013.“Executive board composition and bank risk taking." Journal of Corporate Finance 28:2: 48-65.

Bick, A. 2007."Pitfalls in panel threshold models: The role of regime dependent intercepts." Unpublished paper, Goethe University.

Blundell, R. and S. Bond. 2000."GMM estimation with persistent panel data: an application to production functions." Econometric Reviews 19:3: 321-340.

Bonin, J., I. Hasan, and P. Wachtel. 2005."Bank performance, efficiency and ownership in transition countries." Journal of Banking and Finance 29:1: 31-53. 
Booth, J. and D. Deli. 1999."On executives of financial institutions as outside directors." Journal of Corporate Finance 5:3: 227-250.

Bos, J. and M. Koetter. 2011."Handling losses in translog profit models." Applied Economics 43:3: 307-312.

Bourke, P. 1989.“Concentration and other determinants of bank profitability in Europe, North America and Australia." Journal of Banking and Finance 13:1: 65-79.

Boyd, B. 1995."CEO duality and firm performance: A contingency model." Strategic Management Journal 16:4: 301-312.

Boyd, J. and S. Graham. 1986. "Risk, regulation, and bank holding company expansion into nonbanking.” Unpublished paper, Federal Reserve Bank of Minneapolis Quarterly Review. Brunnermeier, M. and L. Pedersen. 2009."Market liquidity and funding liquidity.” Review of Financial Studies 22:6: 2201-2238.

Bushman, R., Q. Chen, E. Engel, and A. Smith. 2004."Financial accounting information, organizational complexity and corporate governance systems." Journal of Accounting and Economics 37:2: 167-201.

Busta, I. 2007."Board effectiveness and the impact of the legal family in the European banking industry.” Unpublished paper, FMA European Conference.

Campbell, K. and A. Minguez-Vera. 2008."Gender diversity in the boardroom and firm financial performance.” Journal of Business Ethics 83:3: 435-451.

Caner, M. and B. Hansen. 2004."Instrumental variable estimation of a threshold model." Econometric Theory 20:5: 813-843.

Carpenter, M. and W. Sanders. 2002.“Top management team compensation: the missing link between CEO pay and firm performance?.” Strategic Management Journal 23:4: 367-375.

Casu, B. and C. Girardone. 2006."Bank competition and efficiency in the single European market." The Manchester School 74:4: 441-468. 
Casu, B. and C. Girardone. 2010."Integration and efficiency convergence in EU banking markets." Omega 38:5: 260-267.

Chan, K. 1993."Consistency and limiting distribution of the least squares estimator of a threshold autoregressive model.” Annals of Statistics 21:1: 520-533.

Chen, C. 2009."Bank efficiency in Sub-Saharan African middle income countries." Unpublished paper, International Monetary Fund.

Child, J. 1972.“Organizational structure, environment and performance: the role of strategic choice." Sociology 6:1: 1-22.

Choi, S. and I. Hasan. 2005.“Ownership, governance, and bank performance: Korean experience." Financial Markets, Institutions and Instruments 14:4: 215-242.

Coles, J., N. Daniel, and L. Naveen. 2008. “Boards: Does one size fit all?.” Journal of Financial Economics 87:2: 329-356.

Cornett, M., A. Marcus and H. Tehranian. 2008."Corporate governance and pay-forperformance: the impact of earnings management." Journal of Financial Economics 87:1: 357373.

Crawford, A., J. Ezzell, and J. Miles. 1995. "Bank CEO pay-performance relations and the effects of deregulation.” Journal of Business 68:2: 231-256.

Daily, C. and D. Dalton. 1992."The relationship between governance structure and corporate performance in entrepreneurial firms." Journal of Business Venturing 7:5: 375-386.

Daily, C. and D. Dalton. 1994. "Bankruptcy and corporate governance: The impact of board composition and structure." Academy of Management Journal 37:6: 1603-1617.

Dalton, D. and C. Daily. 1998."Board independence: So what?.” Corporate Board 19:113: 1519. 
Dalton, D., C. Daily, A. Ellstrand, and J. Johnson. 1998."Meta-analytic reviews of board composition, leadership structure, and financial performance." Strategic Management Journal 19:3: 269-290.

De Jonghe, O., M. Disli, and K. Schoors. 2012."Corporate Governance, Opaque Bank Activities, and Risk/Return Efficiency: Pre-and Post-Crisis Evidence from Turkey." Journal of Financial Services Research 41:1-2: 51-80.

Demirguc-Kunt, A. and H. Huizinga. 2010."Bank activity and funding strategies: The impact on risk and returns." Journal of Financial Economics 98:3: 626-650.

Denis, D. 2001.“Twenty-five years of corporate governance research... and counting." Review of financial economics 10:3: 191-212.

Diamond, D. and R. Rajan. 2001."Banks, short-term debt and financial crises: theory, policy implications and applications." Unpublished paper, Carnegie-Rochester Conference Series on Public Policy.

Donaldson, L. 1990."The ethereal hand: Organizational economics and management theory." Academy of Management Review 15:3: 369-381.

Donaldson, L. and J. Davis. 1991."Stewardship theory or agency theory: CEO governance and shareholder returns." Australian Journal of Management 16:1: 49-64.

Eagly, A. and L. Carli. 2003."The female leadership advantage: An evaluation of the evidence." The Leadership Quarterly 14:6: 807-834.

Eisenberg, T., S. Sundgren, and M. Wells. 1998.“Larger board size and decreasing firm value in small firms.” Journal of Financial Economics 48:1: 35- 54.

Erkens, D., M. Hung, and P. Matos. 2012. "Corporate governance in the 2007-2008 financial crisis: Evidence from financial institutions worldwide." Journal of Corporate Finance 18:2: $389-411$ 
Fahlenbrach, R., and R. Stulz. 2011."Bank CEO incentives and the credit crisis." Journal of Financial Economics 99:1: 11-26.

Fernando, C., A. May, and W. Megginson. 2012."The value of investment banking relationships: evidence from the collapse of Lehman Brothers." The Journal of Finance 67:1: 235-270.

Finkelstein, S., R. D'aveni. 1994.“CEO duality as a double-edged sword: How boards of directors balance entrenchment avoidance and unity of command." Academy of Management Journal 37:5: 1079-1108.

Finkelstein, S. and D. Hambrick. 1996."Strategic leadership: Top executives and their effects on organization." Unpublished paper, West Publishing Company.

Francis, B., I. Hasan, Q. Wu. 2012."Do Corporate Boards Affect Firm Performance? New Evidence from the Financial Crisis." Unpublished paper, Bank of Finland.

Francoeur, C., R. Labelle, and B. Sinclair-Desgagné. 2008. "Gender diversity in corporate governance and top management." Journal of Business Ethics 81:1: 83-95.

Fries, S. and A. Taci. 2005.“Cost efficiency of banks in transition: Evidence from 289 banks in 15 post-communist countries." Journal of Banking and Finance 29:1: 55-81.

Frye, M. 2004."Equity-based compensation for employees: firm performance and determinants." Journal of Financial Research 27:1: 31-54.

Furfine, C. 2001."Banks as monitors of other banks: Evidence from the overnight federal funds market.” Journal of Business 74:1: 33-57.

Gaganis, C. and F. Pasiouras. 2013."Financial supervision regimes and bank efficiency: International evidence.” Journal of Banking and Finance 37:12: 5463-5475.

Gillan, S. and L. Starks. 2000. "Corporate governance proposals and shareholder activism: The role of institutional investors.” Journal of Financial Economics 57:1: 275-305. 
Goddard, J., P. Molyneux, and J. Wilson. 2004. "The profitability of European banks: a crosssectional and dynamic panel analysis." The Manchester School 72:3: 363-381.

Goodwin-Stewart, J. and P. Kent. 2006."Relation between external audit fees, audit committee characteristics and internal audit." Accounting and Finance 46:3: 387-404.

Gropp, R., C. Gruendl, and A. Guettler. 2013.“The Impact of Public Guarantees on Bank RiskTaking: Evidence from a Natural Experiment.” Review of Finance 18:6:1-32.

Gropp, R., J. Vesala, and G. Vulpes. 2006.“Equity and bond market signals as leading indicators of bank fragility." Journal of Money, Credit and Banking 38:2: 399-428.

Grossman, S. and O. Hart. 1983.“An analysis of the principal-agent problem.” Econometrica Journal of the Econometric Society 51:1: 7-45.

Hagendorff, J. 2014. Corporate Governance in Banking, in Oxford Handbook of Banking, Oxford: Oxford University Press.

Hambrick, D. 1995."Fragmentation and the other problems CEOs have with their top management teams." California Management Review 37:3: 110-127.

Hansen, B. 1997."Inference in TAR models." Studies in Nonlinear Dynamics and Econometrics 2:1: 1-14.

Hansen, B. 1999.“Threshold effects in non-dynamic panels: estimation, testing and inference.” Journal of Econometrics 93:1: 345-368.

Harris, M. and A. Raviv. 1979.“'Optimal incentive contracts with imperfect information.” Journal of Economic Theory 20:2: 231-259.

Hasan, I. and K. Marton. 2003."Development and efficiency of the banking sector in a transitional economy: Hungarian experience.” Journal of Banking and Finance 27:12: 22492271. 
He, J. and H. Wang. 2009. "Innovative knowledge assets and economic performance: The asymmetric roles of incentives and monitoring." Academy of Management Journal 52:5: 919938.

Henderson, A. and J. Fredrickson. 2001."Top management team coordination needs and the CEO pay gap: A competitive test of economic and behavioural views." Academy of Management Journal 44:1: 96-117.

Hillegeist, S. and F. Penalva. 2003. Stock option incentives and firm performance. Unpublished paper, Social Science.

Hubbard, R. and D. Palia. 1995."Executive pay and performance Evidence from the US banking industry." Journal of Financial Economics 39:1: 105-130.

Hughes, P. and J. Mester. 2010."Efficiency in banking theory and evidence.” Oxford: Oxford University Press.

Hughes, P. and J. Mester. 2013."Measuring the performance of banks: theory, practice, evidence, and some policy implications." Unpublished paper, the State University of New Jersey.

Iannotta, G., G. Nocera, and A. Sironi. 2007.“Ownership structure, risk and performance in the European banking industry.” Journal of Banking and Finance 31:7: 2127-2149.

Isik, I. and M. Hassan. 2002."Technical, scale and allocative efficiencies of Turkish banking industry." Journal of Banking and Finance 26:4: 719-766.

Isik, I., and M. Kabir Hassan. 2003."Financial deregulation and total factor productivity change: An empirical study of Turkish commercial banks." Journal of Banking and Finance 27:8: $1455-1485$

Jensen, M. 1993.“The modern industrial revolution, exit, and the failure of internal control systems.” The Journal of Finance 48:3: 831-880. 
Jensen, M. and W. Meckling. 1976.“Theory of the firm: Managerial behaviour, agency costs and ownership structure.” Journal of Financial Economics 3:4: 305-360.

Jensen, M. and K. Murphy. 1990.“Performance pay and top-management incentives.” Journal of Political Economy 98:2: 225-264.

Jondrow, J., C. Knox Lovell, I. Materov, and P. Schmidt. 1982.“'On the estimation of technical inefficiency in the stochastic frontier production function model." Journal of Econometrics 19:2: $233-238$.

Kirkpatrick, G. 2009.“Corporate governance lessons from the financial crisis.” Unpublished paper, OECD.

Klapper, L. and I. Love. 2004.“Corporate governance, investor protection, and performance in emerging markets." Journal of Corporate Finance 10:5: 703-728.

Kremer, S., A. Bick, and D. Nautz. 2013.“Inflation and growth: new evidence from a dynamic panel threshold analysis." Empirical Economics 44:2: 861-878.

Koetter, M. 2006.“Measurement Matters-Alternative Input Price Proxies for Bank Efficiency Analyses.” Journal of Financial Services Research 30:2: 199-227.

Laeven, L. and R. Levine. 2009."Bank governance, regulation and risk taking." Journal of Financial Economics 93:2: 259-275.

Lawrence, P. and J. Lorsch. 1967. "Differentiation and integration in complex organizations." Administrative Science Quarterly 12:1: 1-47.

Lepetit, L., E. Nys, P. Rous, and A. Tarazi. 2008. "Bank income structure and risk: An empirical analysis of European banks." Journal of Banking and Finance 32:8: 1452-1467.

Levine, R. 2004."The corporate governance of the banks: A concise discussion of concepts and evidence.” Unpublished paper, World Bank. 
Liang, Q., P. Xu, and P. Jiraporn. 2013.“Board characteristics and Chinese bank performance.” Journal of Banking and Finance 37:8: 2953-2968.

Lin, X., and Y. Zhang. 2009."Bank ownership reform and bank performance in China." Journal of Banking and Finance 33:1: 20-29.

Linck, J., J. Netter, and T. Yang. 2008.“The determinants of board structure.” Journal of Financial Economics 87:2: 308-328.

Lipton, M. and J. Lorsch. 1992.“A modest proposal for improved corporate governance.” The Business Lawyer 48:1: 59-77.

Lozano-Vivas, A. and F. Pasiouras. 2010."The impact of non-traditional activities on the estimation of bank efficiency: international evidence." Journal of Banking and Finance 34:7: 1436-1449.

Mensah, E., J. Abor, A. Aboagye, and C. Adjasi. 2012."Enhancing the Economic Growth of Africa: Does Banking Sector Efficiency Matter?." Research in Accounting in Emerging Economies 12:1: 1-23.

Micco, A., U. Panizza, and M. Yanez. 2007."Bank ownership and performance. Does politics matter?." Journal of Banking and Finance 31:1: 219-241.

Miller, S. and A. Noulas. 1997."Portfolio mix and large-bank profitability in the USA.” Applied Economics 29:4: 505-512.

Mishra, C. and J. Nielsen. 2000."Board independence and compensation policies in large bank holding companies." Financial Management 29:3: 51-69.

Murphy, K. 1999.“Executive compensation.” Handbook of Labour economics 3:1: 2485-2563. Myers, S. 1977."Determinants of corporate borrowing." Journal of Financial Economics 5:2: 147-175. 
Pasiouras, F., S. Tanna, and C. Zopounidis. 2009.“The impact of banking regulations on banks' cost and profit efficiency: Cross-country evidence." International Review of Financial Analysis 18:5: 294-302.

Pathan, S. 2009.“Strong boards, CEO power and bank risk-taking.” Journal of Banking and Finance 33:7: 1340-1350.

Pathan, S. and R. Faff. 2013."Does board structure in banks really affect their performance?." Journal of Banking and Finance 37:5: 1573-1589.

Pathan, S. and M. Skully. 2010."Endogenously structured boards of directors in banks." Journal of Banking and Finance 34:7: 1590-1606.

Peni, E. and S. Vähämaa. 2012."Did good corporate governance improve bank performance during the financial crisis?.” Journal of Financial Services Research 41:1-2: 19-35.

Pfeffer, J. 1972."Size and composition of corporate boards of directors: The organization and its environment." Administrative Science Quarterly 17:2: 218-228.

Pi, L. and S. Timme. 1993. "Corporate control and bank efficiency." Journal of Banking and Finance 17:2: 515-530.

Radic, N., F. Fiordelisi, and C. Girardone. 2012."Efficiency and risk-taking in pre-crisis investment banks.” Journal of Financial Services Research 41:1-2: 81-101.

Rechner, P. and D. Dalton. 1989.“The impact of CEO as board chairperson on corporate performance: evidence vs. rhetoric." The Academy of Management Executive 3:2: 141-143.

Robinson, G. and K. Dechant. 1997."Building a business case for diversity.” The Academy of Management Executive 11:3: 21-31.

Roodman, D. 2009."How to do xtabond2: An introduction to difference and system GMM in Stata.” Stata Journal 9:1: 86.

Santomero, A. 1997."Deposit insurance: do we need it and why?.” Unpublished paper, Cyprus Economic Society. 
Shrader, C., V. Blackburn, and P. Iles. 1997."Women in management and firm financial performance: An exploratory study.” Journal of Managerial Issues 9:3: 355-372.

Sironi, A. 2003.“Testing for market discipline in the European banking industry: Evidence from subordinated debt issues." Journal of Money, Credit, and Banking 35:3: 443-472.

Staikouras, P., C. Staikouras, and M. Agoraki. 2007."The effect of board size and composition on European bank performance." European Journal of Law and Economics 23:1: 1-27.

Sun, L. and T. Chang. 2011."A comprehensive analysis of the effects of risk measures on bank efficiency: Evidence from emerging Asian countries.” Journal of Banking and Finance 35:7: $1727-1735$

Tanna, S., F. Pasiouras, and M. Nnadi. 2011."The effect of board size and composition on the efficiency of UK banks." International Journal of the Economics of Business 18:3: 441-462.

Vafeas, N. 1999. "Board meeting frequency and firm performance." Journal of Financial Economics 53:1: 113-142.

Vallascas, F. and J. Hagendorff. 2013.“CEO Bonus Compensation and Bank Default Risk: Evidence from the US and Europe.” Financial Markets, Institutions and Instruments 22:2: 4789.

Weisbach, M. 1988.“'Outside directors and CEO turnover.” Journal of Financial Economics 20:1: 431-460.

Westphal, J. 1998."Board games: How CEOs adapt to increases in structural board independence from management." Administrative Science Quarterly 43:3: 511-537.

Westphal, J. 1999.“Collaboration in the boardroom: Behavioural and performance consequences of CEO-board social ties.” Academy of Management Journal 42:1: 7-24.

Windmeijer, F. 2005. "A finite sample correction for the variance of linear efficient two-step GMM estimators.” Journal of Econometrics 126:1: 25-51. 
Wiseman, R. and L. Gomez-Mejia. 1998. "A behavioural agency model of managerial risk taking." Academy of Management Review 23:1: 133-153.

Xie, B., W. Davidson, and P. DaDalt. 2003.“Earnings management and corporate governance: the role of the board and the audit committee." Journal of Corporate Finance 9:3: 295-316. Yermack, D. 1996."Higher market valuation of companies with a small board of directors." Journal of Financial Economics 40:1: 185-211.

Zajac, E. and J. Westphal. 1995.“Accounting for the explanations of CEO compensation: Substance and symbolism.” Administrative Science Quarterly 40:2: 283-308. 
Table1. Recent studies on the relationship between corporate governance and bank performance.

\begin{tabular}{|c|c|c|c|c|c|}
\hline References & Countries in Sample & Years in sample & $\begin{array}{c}\text { Specialisation } \\
\text { of banks }\end{array}$ & $\begin{array}{c}\text { Measure of } \\
\text { performance }\end{array}$ & Methodology \\
\hline $\begin{array}{l}\text { Pathan and } \\
\text { Faff (2013) }\end{array}$ & United States & $1997-2011$ & $\begin{array}{l}\text { Bank Holding } \\
\text { Companies } \\
\text { (BHCs) }\end{array}$ & $\begin{array}{l}\text { Tobin's Q, } \\
\text { ROA,ROE,POI } \\
\text { ratios }\end{array}$ & $\begin{array}{l}\text { Two-step } \\
\text { 'system' } \\
\text { GMM } \\
\text { estimator }\end{array}$ \\
\hline $\begin{array}{l}\text { Liang et al. } \\
\text { (2013) }\end{array}$ & China & 2003-2010 & Commercial & ROA and ROE & $\begin{array}{l}\text { Two-step } \\
\text { 'system' } \\
\text { GMM } \\
\text { estimator }\end{array}$ \\
\hline $\begin{array}{l}\text { Adams and } \\
\text { Mehran } \\
\text { (2012) }\end{array}$ & United States & 1965-1999 & $\begin{array}{l}\text { Bank Holding } \\
\text { Companies } \\
\text { (BHCs) }\end{array}$ & $\begin{array}{l}\text { Tobin's } Q \text { and } \\
\text { ROA. }\end{array}$ & $\begin{array}{c}\text { Fixed-effect } \\
\text { estimator }\end{array}$ \\
\hline $\begin{array}{l}\text { Aebi et al. } \\
\text { (2012) }\end{array}$ & United States & 2007-2009 & $\begin{array}{l}\text { Commercial } \\
\text { and Saving } \\
\text { banks }\end{array}$ & $\begin{array}{l}\text { Buy-and hold } \\
\text { returns, ROA } \\
\text { and ROE }\end{array}$ & $\begin{array}{l}\text { Time-series } \\
\text { regressions }\end{array}$ \\
\hline $\begin{array}{l}\text { Beltratti and } \\
\text { Stulz (2012) }\end{array}$ & United States & $2007-2008$ & $\begin{array}{l}\text { Commercial } \\
\text { banks }\end{array}$ & $\begin{array}{l}\text { Buy-and hold } \\
\text { returns }\end{array}$ & $\begin{array}{c}\text { Cross- } \\
\text { sectional } \\
\text { regressions }\end{array}$ \\
\hline $\begin{array}{l}\text { Erkens et al. } \\
\quad(2012)\end{array}$ & $\begin{array}{c}\text { Australia, Austria, Belgium, Bermuda, Brazil, Canada, } \\
\text { China,Cyprus,Denmark,Finland,France,Germany,Greece,Iceland,India,Ireland,Italy,Liechtenstein, } \\
\text { Luxembourg, Morocco, Netherlands, Norway, Portugal, Russia, Spain, Sweden, Switzerland, United } \\
\text { Kingdom and United States }\end{array}$ & $2007-2008$ & $\begin{array}{l}\text { Commercial } \\
\text { banks, } \\
\text { brokerages, } \\
\text { and insurance } \\
\text { companies }\end{array}$ & $\begin{array}{l}\text { Buy-and hold } \\
\text { returns }\end{array}$ & $\begin{array}{l}\text { OLS and } \\
\text { Tobit } \\
\text { regressions }\end{array}$ \\
\hline $\begin{array}{l}\text { Tanna et al. } \\
\text { (2011) }\end{array}$ & United Kingdom & 2001-2006 & $\begin{array}{l}\text { Commercial, } \\
\text { saving and } \\
\text { investment } \\
\text { banks* }\end{array}$ & $\begin{array}{l}\text { Efficiency (Data } \\
\text { Envelopment } \\
\text { Analysis-DEA) }\end{array}$ & OLS \\
\hline $\begin{array}{l}\text { Fahlenbrach } \\
\text { and Stulz } \\
(2011)\end{array}$ & United States & $2007-2008$ & $\begin{array}{l}\text { Commercial } \\
\text { banks }\end{array}$ & $\begin{array}{l}\text { Buy-and hold } \\
\text { returns }\end{array}$ & $\begin{array}{l}\text { Cross- } \\
\text { sectional } \\
\text { regressions }\end{array}$ \\
\hline $\begin{array}{l}\text { Andres and } \\
\text { Vallelado } \\
\text { (2008) }\end{array}$ & Spain, Italy, France, Canada, United States, and United Kingdom & $1995-2005$ & $\begin{array}{c}\text { Commercial } \\
\text { banks }\end{array}$ & $\begin{array}{l}\text { Tobin's Q, ROA } \\
\text { and annual } \\
\text { returns of bank } \\
\text { shareholders }\end{array}$ & $\begin{array}{l}\text { Two-step } \\
\text { 'system' } \\
\text { GMM } \\
\text { estimator }\end{array}$ \\
\hline $\begin{array}{l}\text { Choi and } \\
\text { Hasan } \\
(2005)\end{array}$ & Korea & 1998-2002 & $\begin{array}{l}\text { Commercial } \\
\text { banks }\end{array}$ & $\begin{array}{l}\text { ROA, ROE and } \\
\text { Efficiency }\end{array}$ & OLS \\
\hline $\begin{array}{l}\text { Mishra and } \\
\text { Nielsen } \\
(2000)\end{array}$ & United States & 1975-1989 & $\begin{array}{l}\text { Bank Holding } \\
\text { Companies } \\
\text { (BHCs) }\end{array}$ & ROA and ROE & $\begin{array}{l}\text { OLS and } \\
\text { 2SLS }\end{array}$ \\
\hline $\begin{array}{l}\text { Pi and } \\
\text { Timme } \\
\text { (1993) }\end{array}$ & United States & $1987-1990$ & $\begin{array}{c}\text { Bank Holding } \\
\text { Companies } \\
\text { (BHCs) }\end{array}$ & $\begin{array}{l}\text { ROA and } \\
\text { Efficiency }\end{array}$ & $\begin{array}{l}\text { OLS and } \\
\text { Tobit } \\
\text { regressions }\end{array}$ \\
\hline
\end{tabular}


Table 2. Definitions of variables used in the fixed effect and dynamic panel estimations.

\begin{tabular}{|c|c|}
\hline Variables & Measures \\
\hline \multicolumn{2}{|l|}{ Corporate governance (explanatory variables) } \\
\hline Board size (BS) & The number of members in the board (we use the natural logarithm in the fixed effect and dynamic panel estimations) \\
\hline Board composition \% (IND) & The percentage of independent directors \\
\hline Gender diversity(GD) & The percentage of female directors \\
\hline CEO 'internally' hired (CEOIN) & A dummy that takes the value of 1 if the $\mathrm{CEO}$ is the founder or has a long term relationship with the bank, and 0 otherwise \\
\hline CEO duality (CEODUAL) & A dummy that takes the value of 1 if the $\mathrm{CEO}$ chairs the board as well, and 0 otherwise \\
\hline CEO tenure (CEOTEN) & The number of years that the $\mathrm{CEO}$ has served in the position (we use the natural logarithm in the fixed and dynamic panel estimations) \\
\hline CEO age (CEOAGE) & The age of the CEO (we use the natural logarithm, in the fixed and dynamic panel estimations) \\
\hline Executives' Compensation (bonus \&base salary) (EXECASH) & The cash compensation of the top management team, which includes base salary and bonus (we use the natural logarithm in the fixed and dynamic panel estimations) \\
\hline Executives' Compensation (equity) (EXEEQ) & The equity compensation of the top management team which includes restricted stock and stock options (we use the natural logarithm in the fixed and dynamic panel estimations) \\
\hline CEO Compensation (bonus \&base salary) (CEOCASH) & The cash compensation of the $\mathrm{CEO}$ which includes base salary and bonus (we use the natural logarithm in the fixed and dynamic panel estimations) \\
\hline CEO Compensation (equity) (CEOEQ) & The equity compensation of the $\mathrm{CEO}$ which includes restricted stock and stock options (we use the natural logarithm in the fixed and dynamic panel) \\
\hline Executives' bonus incentive(EXEBON) & The ratio of bonus over executives' total cash compensation \\
\hline CEO's bonus incentive (CEOBON) & The ratio of bonus over CEOs' total cash compensation \\
\hline Board ownership \% (BOARDOWN) & The percentage shares that the directors hold \\
\hline CEO ownership \% (CEOOWN) & The percentage shares that the $\mathrm{CEO}$ holds \\
\hline Number of board committees (NBCOM) & The number of board committees (we use the natural logarithm in the fixed and dynamic panel estimations) \\
\hline Fees paid for board meetings (FBCOM) & Fees paid to directors for attending the board committees (we use the natural logarithm in the fixed and dynamic panel estimations) \\
\hline Number of audit committee meetings(NMAUD) & Number of meetings of audit committee (we use the natural logarithm in the fixed and dynamic panel estimations) \\
\hline Number of Segments (SEG) & Number of different business segments (we use the natural logarithm in the fixed and dynamic panel estimations) \\
\hline Number of Subsidiaries (SUBS) & Number of subsidiaries (we use the natural logarithm in the fixed and dynamic panel estimations) \\
\hline \multicolumn{2}{|l|}{ Performance measures (dependent variables) } \\
\hline 1. Return on average assets (ROAA) & The net income before interest and taxes as a proportion of the average book value of total assets. \\
\hline 2. Return on average equity (ROAE) & The net income after tax as a percentage of the average book value of total equity \\
\hline 3. Pre-tax operating income (POI) & The pre-tax operating income as a percentage of the average total assets \\
\hline 4. Profit efficiency (EFF) & Efficiency scores obtained from the SFA \\
\hline \multicolumn{2}{|l|}{ Other control variables } \\
\hline Equity over total assets (E/TA) & The ratio of equity over total asset \\
\hline Investment banking fees (FEES) & The ratio of net fees, commission and net trading income over total assets \\
\hline Other earnings assets (EARN) & The ratio of trading securities, derivatives, treasury bills and bonds over total assets \\
\hline Risk to default (RISK) & Z-score $=(1+$ Average ROE $) /$ Standard Deviation of ROE \\
\hline Volatility Implied Index (VIX) & Chicago Board Options Exchange Volatility Index \\
\hline Post Sarbanes-Oxley Act period (PSOX) & A dummy, which takes the value of 0 if year is $2000-2001$ and the value of 1 otherwise. \\
\hline Crisis period (CRS) & A dummy, which takes the value of 1 if year is $2007-2010$. \\
\hline
\end{tabular}


Table 3. Descriptive statistics of the variables employed in the fixed effect and dynamic panel regressions.

\begin{tabular}{|c|c|c|c|c|c|}
\hline Variables & Mean & SD & MIN & MAX & Median \\
\hline \multicolumn{6}{|c|}{ Panel A: Corporate governance variables } \\
\hline BS & 8.3 & 3.5 & 5 & 16 & 9 \\
\hline IND & 0.66 & 0.25 & 0.4 & 0.92 & 0.71 \\
\hline GD & 0.11 & 0.1 & 0 & 0.44 & 0.11 \\
\hline CEOIN & 0.65 & 0.48 & 0 & 1 & 1 \\
\hline CEODUAL & 0.72 & 0.49 & 0 & 1 & 1 \\
\hline CEOTEN & 7.74 & 8.25 & 0 & 41 & 5 \\
\hline CEOAGE & 55.35 & 8.18 & 39 & 72 & 56 \\
\hline BOARDOWN & 12.27 & 15.43 & 0 & 67.21 & 6.68 \\
\hline CEOOWN & 6.08 & 8.59 & 0.01 & 55.71 & 1.83 \\
\hline NBCOM & 3.32 & 1.20 & 0 & 6 & 3 \\
\hline FBCOM & 0.31 & 1.031 & 0 & 1,25 & 0 \\
\hline NMAUD & 8.01 & 4.04 & 0 & 18 & 8 \\
\hline SEG & 3.04 & 1.76 & 0 & 8 & 3 \\
\hline SUB & 114.6 & 236.4 & 0 & 1255 & 15 \\
\hline EXECASH & 16,500 & 20,700 & 0 & 139,000 & 7,897 \\
\hline EXEEQ & 20,100 & 30,300 & 0 & 209,000 & 7,234 \\
\hline CEOCASH & 4,303 & 6,063 & 0 & 41,200 & 1,950 \\
\hline CEOEQ & 5,720 & 8,219 & 0 & 42,400 & 1,356 \\
\hline \multicolumn{6}{|c|}{ Panel B: Bank-specific and country level variables } \\
\hline E/TA & 0.2324 & 0.2456 & 0.0105 & 0.97 & 0.1022 \\
\hline FEES & 0.4703 & 0.8905 & 0.0004 & 5.21 & 0.0676 \\
\hline EARN & 0.6094 & 0.3765 & 0.0001 & 3.756 & 0.6638 \\
\hline RISK & 3.0961 & 6.3524 & -42.59 & 52.82 & 2.1066 \\
\hline VIX & 20.97 & 7.5946 & 11.56 & 40 & 21.68 \\
\hline \multicolumn{6}{|c|}{ Panel C: Bank performance measures } \\
\hline ROAE & 8.02 & 29.77 & -305.05 & 122.82 & 8.97 \\
\hline ROAA & 1.96 & 11.73 & -50.6 & 72.97 & 0.74 \\
\hline POI & 3.32 & 14.99 & -63.15 & 91.17 & 0.99 \\
\hline EFF & 0.65 & 0.39 & 0.12 & 0.97 & 0.78 \\
\hline \multicolumn{6}{|c|}{ Panel D: Year by year corporate governance variables } \\
\hline Year & BS & IND & CEODUAL & CEOOWN & BOARDOWN \\
\hline 2000 & 8.7 & 0.66 & 0.80 & 6.78 & 10.40 \\
\hline 2001 & 8.2 & 0.65 & 0.92 & 5.68 & 9.75 \\
\hline 2002 & 7.8 & 0.60 & 0.87 & 6.92 & 9.89 \\
\hline 2003 & 7.4 & 0.60 & 0.80 & 6.91 & 11.11 \\
\hline 2004 & 8.9 & 0.69 & 0.87 & 7.97 & 9.23 \\
\hline 2005 & 8.5 & 0.68 & 0.81 & 7.45 & 9.64 \\
\hline 2006 & 9.0 & 0.69 & 0.83 & 7.30 & 13.57 \\
\hline 2007 & 8.5 & 0.66 & 0.82 & 6.39 & 14.20 \\
\hline 2008 & 8.1 & 0.64 & 0.60 & 2.84 & 13.05 \\
\hline 2009 & 8.4 & 0.66 & 0.59 & 7.35 & 14.84 \\
\hline 2010 & 8.1 & 0.66 & 0.56 & 5.27 & 12.91 \\
\hline 2011 & 8.0 & 0.66 & 0.47 & 4.08 & 14.57 \\
\hline 2012 & 8.4 & 0.67 & 0.46 & 3.73 & 14.05 \\
\hline
\end{tabular}

Notes: the Table reports the descriptive statistics of the variables employed in the fixed effect and dynamic panel regressions All variables are in absolute values except of the compensation determinants (EXECASH,EXEEQ,CEOCASH and CEOEQ) which are in million dollars. BS: the number of members in the board; IND: the percentage of independent directors; GD: the percentage of female directors; CEOIN: a dummy that takes the value of 1 if the CEO is the founder or has a long term relationship with the bank, and 0 otherwise; CEODUAL: a dummy that takes the value of 1 if the CEO chairs the board as well, and 0 otherwise; CEOTEN: the number of years that the CEO has served in the position; CEOAGE: the age of the CEO; BOARDOWN: the percentage shares that the directors hold; CEOOWN: the percentage shares that the CEO holds; NBCOM: the number of board committees; NMAUD: number of meetings of audit committee; FBCOM: fees paid to directors for attending the board committees; SEG: the number of different business segments; SUBS: Number of subsidiaries; EXECASH: the cash compensation of the top management team which includes base salary and bonus; EXEEQ: the equity compensation of the top management team which includes restricted stock and stock options; CEOCASH: the cash compensation of the CEO which includes base salary and bonus; CEOEQ: the equity compensation of the CEO which includes restricted stock and stock options; E/TA: equity over total assets; FEES: of net fees, commission and net trading income over total assets; EARN: ratio of trading securities, derivatives, treasury bills and bonds over total assets; RISK: Z-score $=(1+\mathrm{ROE}) / \mathrm{Standard}$ Deviation of ROE; VIX: Volatility Implied Index (Chicago Board Options Exchange Volatility Index); ROAE: net income after tax as a percentage of the average book value of total equity; ROAA: net income before interest and taxes as a proportion of the average book value of total assets; POI: pre-tax operating income as a percentage of the average total assets; EFF: efficiency scores obtained from the SFA. 
Table 4. Correlation of efficiency and accounting-based ratios.

\begin{tabular}{lclll}
\hline & EFF & ROAE & ROAA & POI \\
\hline EFF & 1 & & & \\
ROAE & 0.0952 & 1 & & \\
ROAA & 0.0889 & 0.6915 & 1 & 1 \\
POI & 0.1107 & 0.6701 & 0.7913 & 1 \\
\hline
\end{tabular}

Notes: the Table shows the correlation of efficiency and accounting-based ratios for a sample of US investment banks over 2000-2012 periods. EFF denotes the profit efficiency scores obtained from the SFA, ROAE is the return on equity, ROAA is the return on assets and POI denotes the pre-tax operating income. 
Table 5. Dynamic panel regressions over the period 2000 to 2012 for US investment bank performance (board structure and CEO characteristics).

\begin{tabular}{|c|c|c|c|c|c|c|c|c|}
\hline & & $\begin{array}{ll}\text { Board } & \text { Structure } \\
\end{array}$ & & & & $\begin{array}{ll}\text { CEO } & \text { Charac } \\
\end{array}$ & & \\
\hline VARIABLES & ROAE(1) & ROAA $(2)$ & POI(3) & EFF(4) & ROAE(5) & ROAA(6) & POI(7) & $\mathrm{EFF}(8)$ \\
\hline \multirow[t]{2}{*}{ Lag performance } & $0.3539^{* * *}$ & $0.3405^{* *}$ & $0.3612 * * *$ & $0.986 * * *$ & $0.2088^{* *}$ & $0.1874 * *$ & $0.4721 * *$ & $0.976^{* * * *}$ \\
\hline & $(0.1426)$ & $(0.1664)$ & $(0.1207)$ & $(0.142)$ & $(0.0906)$ & $(0.087)$ & $(0.1974)$ & $(0.178)$ \\
\hline \multirow[t]{2}{*}{ E/TA } & 0.3842 & $-0.5491 * *$ & -0.1291 & -0.00016 & $-1.412^{* * * *}$ & $-0.5543 * *$ & $-0.6541 * *$ & 0.00143 \\
\hline & $(0.4728)$ & $(0.2332)$ & $(0.0916)$ & $(0.00052)$ & $(0.268)$ & $(0.2681)$ & $(0.2962)$ & (0.00119) \\
\hline \multirow[t]{2}{*}{ EARN } & -0.0312 & $-0.0595 * * *$ & 0.0470 & - & 0.0319 & $-0.0317 * *$ & -0.0115 & \\
\hline & $(0.0406)$ & $(0.0205)$ & $(0.0387)$ & & $(0.0420)$ & $(0.0178)$ & $(0.0207)$ & - \\
\hline \multirow[t]{2}{*}{ FEES } & -0.0515 & 0.0240 & $0.0611^{* *}$ & - & $0.5491 * * *$ & 0.3566 & -0.0019 & \\
\hline & $(0.0674)$ & $(0.0486)$ & $(0.0287)$ & & $(0.131)$ & $(0.297)$ & $(0.0415)$ & - \\
\hline \multirow[t]{2}{*}{ RISK } & 0.0007 & -0.0007 & 0.0024 & $-3.15 e-06$ & -0.0003 & 0.0004 & 0.0056 & \\
\hline & $(0.0097)$ & $(0.004)$ & $(0.0037)$ & $(9.49 \mathrm{e}-06)$ & $(0.0047)$ & $(0.0034)$ & $(0.0035)$ & 0.0005 \\
\hline \multirow[t]{2}{*}{ PSOX } & $-0.0959 * *$ & $-0.0397 * * *$ & 0.0398 & 0.00016 & $-0.0564 * * *$ & $-0.0981 * * *$ & -0.0460 & $(0.0013)$ \\
\hline & $(0.0477)$ & $(0.0151)$ & $(0.0347)$ & $(0.0001)$ & $(0.0161)$ & $(0.0272)$ & 0.0750 & $-0.000135^{* *}$ \\
\hline \multirow[t]{2}{*}{ VIX } & $-0.0079 * *$ & $-0.0043 * * *$ & $-0.0066^{* *}$ & $-0.0000^{*}$ & $-0.0063^{* *}$ & $-0.0067 * *$ & $8.38 \mathrm{e}-06$ & $(0.00059)$ \\
\hline & $(0.0031)$ & $(0.0011)$ & 0.0033 & $(9.77 \mathrm{e}-06)$ & $(0.0027)$ & $(0.0032)$ & $(0.00590)$ & $-0.00008^{*}$ \\
\hline \multirow[t]{2}{*}{ CRS } & $-0.0906^{*}$ & $-0.0647 * *$ & $-0.0942 *$ & $-0.0001 * *$ & 0.0320 & 0.0431 & $-0.1286^{* * * *}$ & $(0.00004)$ \\
\hline & $(0.0498)$ & $(0.0329)$ & $(0.0562)$ & $(0.00005)$ & $(0.0136)$ & $(0.3281)$ & $(0.0429)$ & 0.00092 \\
\hline \multirow[t]{2}{*}{ BS } & 0.01922 & $-0.0316^{* * * *}$ & $-0.5018 * * *$ & $-0.00017^{*}$ & - & - & - & - \\
\hline & $(0.0351)$ & $(0.0096)$ & $(0.1815)$ & $(0.0001)$ & & & & \\
\hline IND & $\begin{array}{c}0.2335 \\
(0.3347)\end{array}$ & -0.0468 & -0.2072 & -0.00033 & - & - & - & - \\
\hline GD & 0.1131 & 0.0031 & 0.0855 & 0.0000 & - & - & - & - \\
\hline \multirow[t]{2}{*}{ CEOAGE } & & & & & 0.3077 & -0.1195 & -0.0342 & 0.00315 \\
\hline & - & - & - & - & $(0.2703)$ & $(0.3716)$ & $(0.2737)$ & $(0.0105)$ \\
\hline \multirow[t]{2}{*}{ CEOTEN } & & & & & -0.1493 & 0.3609 & -0.0030 & 0.00015 \\
\hline & - & - & - & - & $(0.0705)$ & $(0.3522)$ & $(0.0267)$ & $(0.00012)$ \\
\hline \multirow[t]{2}{*}{ CEOIN } & - & - & - & - & $0.3960 * *$ & $0.1759 * * *$ & $0.183^{* * *}$ & 0.0012 \\
\hline & & & & & $(0.1875)$ & $(0.0635)$ & $(0.079)$ & $(0.0019)$ \\
\hline \multirow[t]{2}{*}{ Constant } & -0.1441 & $0.3732 * * *$ & $1.195 * * *$ & -0.0011 & -0.1271 & 0.5608 & 0.2348 & 0.00749 \\
\hline & $(0.3266)$ & $(0.0830)$ & $(0.3613)$ & $(0.0007)$ & $(1.465)$ & $(1.545)$ & $(1.141)$ & $(0.0404)$ \\
\hline Wald chi2 & $216.22 * * *$ & $94.41 * * *$ & $335.68^{* * *}$ & $479.25 * * *$ & $133478.85 * * *$ & $73.56^{* * * *}$ & $68.30 * * *$ & $145.39 * * *$ \\
\hline $\mathrm{AR}(1)$ test stat & $-2.10 * *$ & $1.69^{*}$ & $-1.69^{*}$ & $-2.27 * *$ & $-1.96^{*}$ & $2.03 * *$ & $-1.72 *$ & $-2.18 * *$ \\
\hline $\mathrm{AR}(2)$ test stat & 0.95 & 0.35 & -0.32 & -0.15 & 0.26 & 0.63 & -1.03 & -0.23 \\
\hline Hansen J-stat & 1 & 0.675 & 0.907 & 0.482 & 0.674 & 0.984 & 0.889 & 0.897 \\
\hline Instruments & 23 & 23 & 23 & 23 & 23 & 23 & 23 & 23 \\
\hline Observations & 184 & 184 & 184 & 184 & 184 & 184 & 184 & 184 \\
\hline Number of banks & 23 & 23 & 23 & 23 & 23 & 23 & 23 & 23 \\
\hline
\end{tabular}


Table 6. Dynamic panel regressions over the period 2000 to 2012 for US investment bank performance (compensation and ownership).

\begin{tabular}{|c|c|c|c|c|c|c|c|c|}
\hline \multicolumn{4}{|c|}{ Compensation } & \multicolumn{5}{|c|}{ Ownership } \\
\hline VARIABLES & ROAE(1) & ROAA(2) & $\mathrm{POI}(3)$ & $\mathrm{EFF}(4)$ & ROAE(5) & ROAA(6) & $\mathrm{POI}(7)$ & $\mathrm{EFF}(8)$ \\
\hline Lag Performance & $\begin{array}{l}0.3789 * * \\
(0.1919)\end{array}$ & $\begin{array}{l}0.4266^{*} \\
(0.2245)\end{array}$ & $\begin{array}{l}0.3098 * * * * \\
(0.0779)\end{array}$ & $\begin{array}{l}0.954 * * * * \\
(0.153)\end{array}$ & $\begin{array}{l}0.2074^{*} \\
(0.1142)\end{array}$ & $\begin{array}{c}0.4392 * * * \\
(0.0955)\end{array}$ & $\begin{array}{c}0.2592^{* *} \\
(.1090)\end{array}$ & $\begin{array}{c}0.972 * * * \\
(0.148)\end{array}$ \\
\hline $\mathrm{E} / \mathrm{TA}$ & $-1.956 * * *$ & $-0.3703^{*}$ & 0.0988 & 0.0007 & -0.0118 & $-0.1747 * * *$ & $-0.4124 * *$ & $-0.000693^{*}$ \\
\hline EARN & $\begin{array}{l}-0.0377 \\
(0.084)\end{array}$ & $\begin{array}{l}-0.0117 \\
(0.0242)\end{array}$ & $\begin{array}{l}-0.0555 \\
(0.0926)\end{array}$ & - & $\begin{array}{l}-0.0446 * * * \\
(0.0169)\end{array}$ & $\begin{array}{c}-0.0255^{* * * * *} \\
(0.0086)\end{array}$ & $\begin{array}{r}-0.0616 * * * \\
(0.0138)\end{array}$ & $\begin{array}{c}-0.004+10) \\
-\end{array}$ \\
\hline FEES & $\begin{array}{l}-0.0225 \\
(0.0505)\end{array}$ & $\begin{array}{c}0.0079 \\
(0.0440)\end{array}$ & $\begin{array}{l}-0.0059 \\
(0.0200)\end{array}$ & - & $\begin{array}{l}0.0554^{*} \\
(0.0278)\end{array}$ & $\begin{array}{l}0.0262^{*} \\
(0.0152)\end{array}$ & $\begin{array}{l}0.0924 * * * \\
(0.0175)\end{array}$ & - \\
\hline RISK & $\begin{array}{l}0.0102^{*} \\
(0.0058)\end{array}$ & $\begin{array}{c}0.0023 \\
(0.00256)\end{array}$ & $\begin{array}{c}0.0018 \\
(0.0014)\end{array}$ & $\begin{array}{l}0.00078 \\
(0.0011)\end{array}$ & $\begin{array}{c}0.0088 \\
(0.0117)\end{array}$ & $\begin{array}{c}0.0028 \\
(0.0019)\end{array}$ & $\begin{array}{l}-0.0041 \\
(0.0119)\end{array}$ & $\begin{array}{l}0.00006 \\
(0.0005)\end{array}$ \\
\hline PSOX & $\begin{array}{c}0.0296 \\
(0.0435)\end{array}$ & $\begin{array}{c}-0.0455 \\
(0.1178)\end{array}$ & $\begin{array}{c}-0.035^{* * *} \\
(0.015)\end{array}$ & $\begin{array}{l}0.00092 \\
(0.0022)\end{array}$ & $\begin{array}{c}-0.0952 \\
(0.1036)\end{array}$ & $\begin{array}{c}-0.0538 \\
(0.0766)\end{array}$ & $\begin{array}{l}-0.1125 \\
(0.1306)\end{array}$ & $\begin{array}{l}0.00011 \\
(0.0003)\end{array}$ \\
\hline VIX & $\begin{array}{l}-0.0045^{*} \\
(0.0024)\end{array}$ & $\begin{array}{c}-0.0026 \\
(0.00225)\end{array}$ & $\begin{array}{c}0.0010 \\
(0.0031)\end{array}$ & $\begin{array}{c}0.00040 \\
(0.00027)\end{array}$ & $\begin{array}{l}-0.0066 \\
(0.0058)\end{array}$ & $\begin{array}{c}-0.0107 * * * \\
(0.0025)\end{array}$ & $\begin{array}{l}-0.0122 * * * \\
(0.0037)\end{array}$ & $\begin{array}{c}-0.0000^{* * * *} * \\
(0.0000)\end{array}$ \\
\hline CRS & $\begin{array}{c}-0.1245^{* *} * \\
(0.0624)\end{array}$ & $\begin{array}{l}0.0534 \\
(0.0543)\end{array}$ & $\begin{array}{l}-0.064 * \\
(0.0362)\end{array}$ & $\begin{array}{c}-0.00066 * * * * \\
(0.00002)\end{array}$ & $\begin{array}{l}-0.1408 * * * \\
(0.0360)\end{array}$ & $\begin{array}{c}-0.1020 * * * * \\
(0.0313)\end{array}$ & $\begin{array}{c}0.0500 \\
(0.1102)\end{array}$ & $\begin{array}{c}-0.0001 * * * * \\
(0.0000)\end{array}$ \\
\hline EXECASH & $\begin{array}{l}-0.0483^{*} \\
(0.0265)\end{array}$ & $\begin{array}{l}-0.1121^{*} \\
(0.0629)\end{array}$ & $\begin{array}{c}0.0215 \\
(0.07055)\end{array}$ & $\begin{array}{l}-0.00016 \\
(0.0003)\end{array}$ & - & - & - & - \\
\hline EXEEQ & $\begin{array}{l}-0.01853 \\
(0.0117)\end{array}$ & $\begin{array}{c}0.0072^{* * * *} \\
(0.00270)\end{array}$ & $\begin{array}{l}-0.0089 \\
(0.0146)\end{array}$ & $\begin{array}{c}0.000278 \\
(0.0005)\end{array}$ & - & - & - & - \\
\hline CEOCASH & $\begin{array}{c}0.0282^{* * * *} \\
(0.0089)\end{array}$ & $\begin{array}{l}-0.0730 \\
(0.0750)\end{array}$ & $\begin{array}{l}0.00618^{* * * *} \\
(0.00115)\end{array}$ & $\begin{array}{c}0.000145 \\
(0.000178)\end{array}$ & - & - & - & - \\
\hline CEOEQ & $\begin{array}{c}0.0069 * * \\
(0.0031)\end{array}$ & $\begin{array}{c}0.0117 * * \\
(0.0052)\end{array}$ & $\begin{array}{l}0.00238 \\
(0.0029)\end{array}$ & $\begin{array}{l}0.000327^{*} \\
(0.000184)\end{array}$ & - & - & - & \\
\hline BOARDOWN & - & - & - & & $\begin{array}{c}-0.0092 * * * \\
(0.0022)\end{array}$ & $\begin{array}{c}-0.0042^{* * *} \\
(0.0014)\end{array}$ & $\begin{array}{c}-0.0081 * * \\
(0.0040)\end{array}$ & $\begin{array}{c}0.00002 \\
(0.00003)\end{array}$ \\
\hline CEOOWN & - & - & - & - & $\begin{array}{c}0.0118^{* *} \\
(0.0055)\end{array}$ & $\begin{array}{l}0.0021 \\
(.0021)\end{array}$ & $\begin{array}{l}0.0100^{*} \\
(0.0056)\end{array}$ & $\begin{array}{l}0.00005^{*} \\
(0.00003)\end{array}$ \\
\hline EXEBON & - & - & - & - & $\begin{array}{l}-0.0060 \\
(0.0331)\end{array}$ & $\begin{array}{l}-0.0182 \\
(0.0146)\end{array}$ & $\begin{array}{l}0.0464 * \\
(0.0277)\end{array}$ & $\begin{array}{c}0.00001 * * * \\
(0.0000)\end{array}$ \\
\hline CEOBON & - & - & - & - & $\begin{array}{c}-0.0053 \\
(0.0441)\end{array}$ & $\begin{array}{c}0.0024 \\
(0.0096)\end{array}$ & $\begin{array}{c}0.0132 \\
(0.0181)\end{array}$ & $\begin{array}{c}0.00001 * * \\
(0.0000)\end{array}$ \\
\hline Constant & $\begin{array}{c}0.8893 \\
(0.6705)\end{array}$ & $\begin{array}{c}0.2944 \\
(0.2165)\end{array}$ & $\begin{array}{c}0.129 \\
(0.796)\end{array}$ & $\begin{array}{l}1.72 * * * \\
(0.335)\end{array}$ & $\begin{array}{c}0.2622 \\
(0.3894)\end{array}$ & $\begin{array}{c}0.4694 * * * \\
(0.1559)\end{array}$ & $\begin{array}{c}0.3653 \\
(0.3599)\end{array}$ & $\begin{array}{l}-2.80 * * * * \\
(0.0981)\end{array}$ \\
\hline Wald chi2 & $324.86 * * *$ & $52.12 * * *$ & $424.60 * * *$ & $412.24 * * *$ & $464.92 * * *$ & $253.27 * * * *$ & $2979.09 * * *$ & $470.30 * * *$ \\
\hline $\mathrm{AR}(1)$ test stat & $-1.72^{*}$ & $-1.86^{*}$ & $-2.04 *$ & $-2.20 * *$ & $-2.16 * *$ & $-1.97 * * *$ & $-2.32 * *$ & $2.08 * *$ \\
\hline $\mathrm{AR}(2)$ test stat & -0.06 & 0.26 & -0.52 & -0.73 & -0.21 & 0.06 & -1.44 & 0.14 \\
\hline Hansen J-stat & 0.829 & 0.595 & 0.252 & 0.286 & 0.522 & 1 & 0.516 & 0.961 \\
\hline Instruments & 23 & 23 & 23 & 23 & 23 & 23 & 23 & 23 \\
\hline Observations & 184 & 184 & 184 & 184 & 184 & 184 & 184 & 184 \\
\hline Number of banks & 23 & 23 & 23 & 23 & 23 & 23 & 23 & 23 \\
\hline $\begin{array}{l}\text { tes: the Table reports th } \\
\text { et income before intere } \\
\text { XECASH: the cash cor } \\
\text { f the CEO which inclu } \\
\text { EO holds; EXEBON: } \\
\text { ecurities, derivatives, tr } \\
\text { if year is 2007-2010; } \\
\text { toblems with thele }\end{array}$ & $\begin{array}{l}\text { ectutives' to } \\
\text { ind bonds o } \\
\text { ty Implied }\end{array}$ & 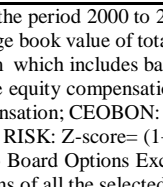 & $\begin{array}{l}\text { iable is the p } \\
\text { operating inco } \\
\text { EEQ the equi } \\
\text { cludes restrict } \\
\text { cash compen } \\
\text { in of ROE; P } \\
\text {. For Volatilil }\end{array}$ & $\begin{array}{l}\text { nvestment bal } \\
\text { age of the ave } \\
\text { no of the top n } \\
\text { ock options; } 1 \\
\text { quity over tot. } \\
\text { vhich takes th } \\
\text { xich tata (VIX- }\end{array}$ & $\begin{array}{l}\text { E: net income a } \\
\text { ssets; 4)EFF: eff } \\
\text { team which inc } \\
\text { N: the percenta } \\
\text { ES: of net fees, } \\
\text { if year is 2000- } \\
\text { ard Options Ex }\end{array}$ & $\begin{array}{l}\text { es that the di } \\
\text { sion and net } \\
\text { dit the value } \\
\text { Volatility Ind }\end{array}$ & 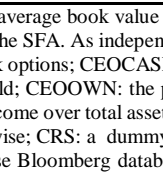 & $\begin{array}{l}\text { lequity; 2) } 2 \text { RO } \\
\text { ariables we emp } \\
\text { cash compensal } \\
\text { tage shares that } \\
\text { RN: ratio of trad } \\
\text { h takes the valu } \\
\text { o avoid collinea }\end{array}$ \\
\hline
\end{tabular}


Table 7. Dynamic panel regressions over the period 2000 to 2012 for US investment bank performance (governance complexity).

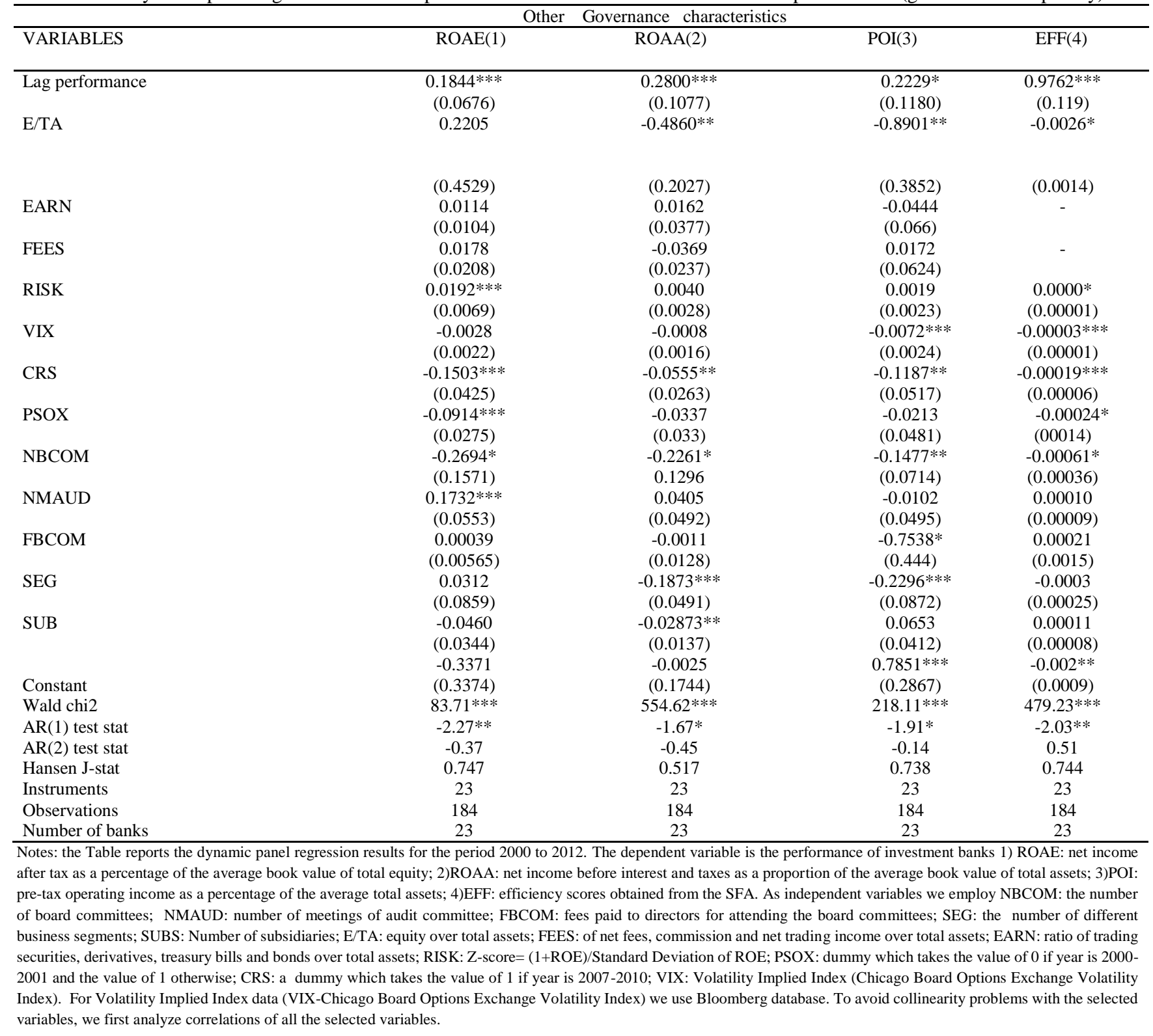


Table 8. Results of dynamic panel threshold estimation with board size as threshold variable.

\begin{tabular}{|c|c|c|}
\hline \multicolumn{3}{|c|}{ Investment banks } \\
\hline \multicolumn{3}{|l|}{ Threshold estimate } \\
\hline $\mathrm{BS}$ & & .30259 \\
\hline $95 \%$ confidence interval & $(2.197$ & 97900) \\
\hline Impact of board size & & S.E \\
\hline$\lambda 1$ & -0.0524 & 0.046 \\
\hline$\lambda 2$ & $-1.3778 * * *$ & 0.416 \\
\hline Impact of covariates & & S.E \\
\hline $\mathrm{E} / \mathrm{TA}$ & -0.538 & 0.505 \\
\hline RISK & 0.0017 & 0.002 \\
\hline EARN & $-0.0302 * *$ & 0.013 \\
\hline FEES & $0.0459 *$ & 0.025 \\
\hline IND & 0.1314 & 0.105 \\
\hline GD & -0.0951 & 0.157 \\
\hline PSOX & $-0.0741 * *$ & 0.034 \\
\hline VIX & $-0.0042 * * *$ & 0.001 \\
\hline$\delta$ & $-0.5948 * * *$ & 0.164 \\
\hline Observations & 184 & \\
\hline Low regime & 117 & \\
\hline High regime & 67 & \\
\hline
\end{tabular}

Notes: the Table reports the estimations for the dynamic panel threshold model. Each regime has at least 5\% of the observations (Hansen, 1999). The threshold value of Board size variable for banks range between 2.1972 and 2.3973. We denote as dependent variable banks' ROAE ( perform $_{i t}$ ), while as the threshold and the regime dependent variable we impose the BS $\left(B S_{i t}\right)$, which represents the natural logarithm of banks' board size. We assume $m_{i t}$ includes a number of explanatory variables. IND: the percentage of independent directors; GD: the percentage of female directors; E/TA: equity over total assets; FEES: of net fees, commission and net trading income over total assets; EARN: ratio of trading securities, derivatives, treasury bills and bonds over total assets; RISK: Z-score $=(1+\mathrm{ROE}) /$ Standard Deviation of ROE; PSOX: dummy which takes the value of 0 if year is 2000 2001 and the value of 1 otherwise; VIX: Volatility Implied Index (Chicago Board Options Exchange Volatility Index). Following Bick (2007), the model accounts for regime dependent intercepts $(\delta)$.

Table 9. Dynamic Threshold Analysis: classification of investment banks into the two identified regimes based on threshold value of Board size.

\begin{tabular}{|c|c|c|c|c|c|c|c|c|c|c|c|c|c|}
\hline \multicolumn{14}{|c|}{ Threshold: Board size } \\
\hline & 2000 & 2001 & 2002 & 2003 & 2004 & 2005 & 2006 & 2007 & 2008 & 2009 & 2010 & 2010 & 2011 \\
\hline Low regime & $70 \%$ & $62 \%$ & $64 \%$ & $64 \%$ & $67 \%$ & $56 \%$ & $56 \%$ & $47 \%$ & $73 \%$ & $65 \%$ & $75 \%$ & $73 \%$ & $62 \%$ \\
\hline High regime & $30 \%$ & $38 \%$ & $36 \%$ & $36 \%$ & $33 \%$ & $44 \%$ & $44 \%$ & $53 \%$ & $27 \%$ & $35 \%$ & $25 \%$ & $27 \%$ & $38 \%$ \\
\hline
\end{tabular}

Notes: Table shows the classification of the investment banks based on the Board size (natural logarithm) threshold value that we obtained following Kremer's et al. (2013) threshold model for dynamic panel. 
Table 10. Results of dynamic panel threshold estimation with board ownership as threshold variable.

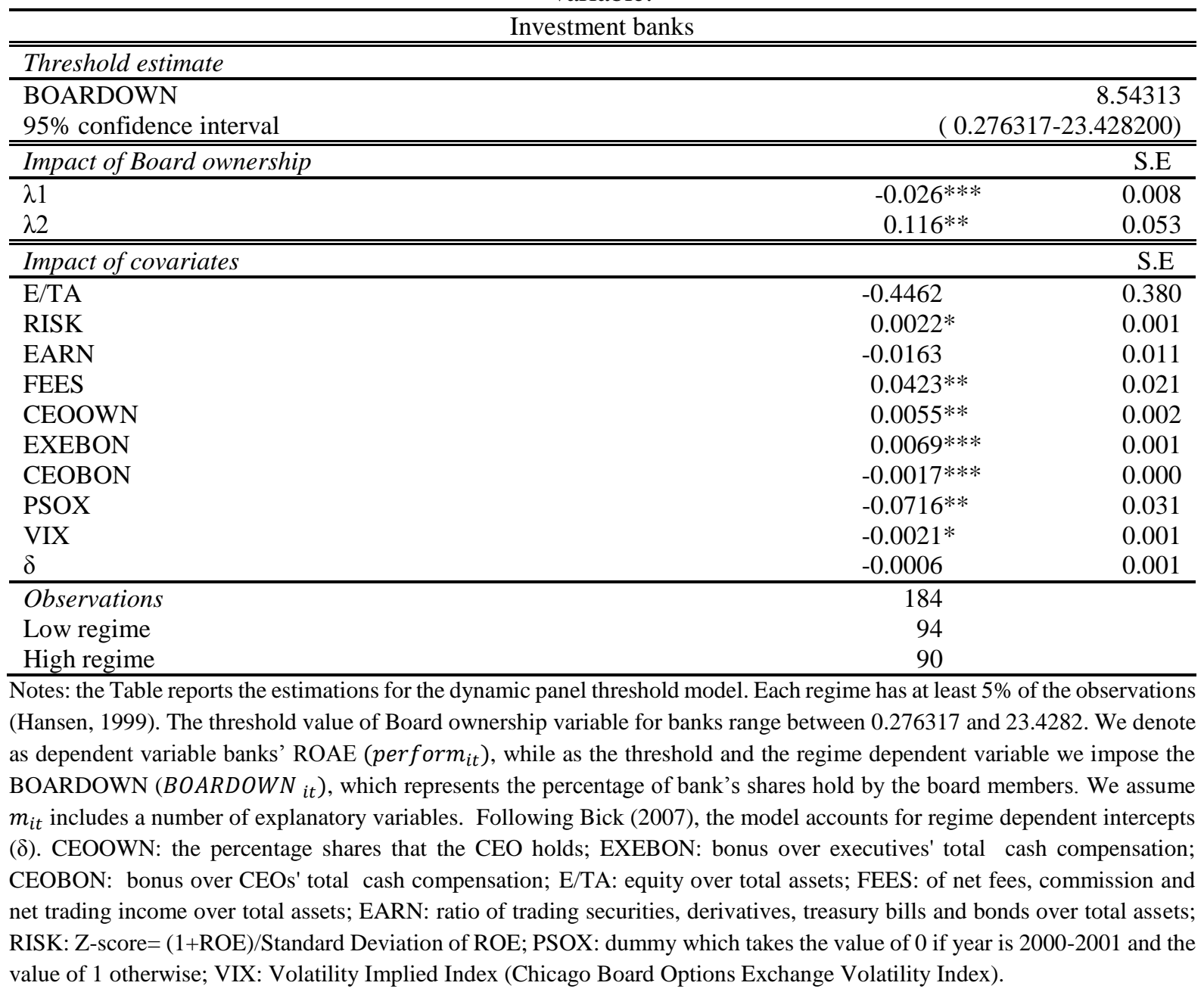

Table 11. Dynamic Threshold Analysis: classification of investment banks into the two identified regimes based on threshold value of Board ownership.

\begin{tabular}{lccccccccccccc}
\hline \multicolumn{1}{l}{ Threshold: Board ownership } & $\mathbf{2 0 0 0}$ & $\mathbf{2 0 0 1}$ & $\mathbf{2 0 0 2}$ & $\mathbf{2 0 0 3}$ & $\mathbf{2 0 0 4}$ & $\mathbf{2 0 0 5}$ & $\mathbf{2 0 0 6}$ & $\mathbf{2 0 0 7}$ & $\mathbf{2 0 0 8}$ & $\mathbf{2 0 0 9}$ & $\mathbf{2 0 1 0}$ & $\mathbf{2 0 1 0}$ & $\mathbf{2 0 1 1}$ \\
Low regime & $70 \%$ & $69 \%$ & $50 \%$ & $57 \%$ & $53 \%$ & $50 \%$ & $44 \%$ & $47 \%$ & $53 \%$ & $35 \%$ & $50 \%$ & $53 \%$ & $46 \%$ \\
High regime & $30 \%$ & $31 \%$ & $50 \%$ & $43 \%$ & $47 \%$ & $50 \%$ & $56 \%$ & $53 \%$ & $47 \%$ & $65 \%$ & $50 \%$ & $47 \%$ & $54 \%$ \\
\hline
\end{tabular}

Notes: Table shows the classification of the investment banks based on the Board ownership threshold value that we obtained following Kremer's et al. (2013) threshold model for dynamic panel. 
iFernando et al. (2012) demonstrate that firms that had as their main equity underwriter Lehman Brothers suffered economically and their earnings experienced a substantial fall.

ii Z-score $=(1+$ ROE $) /$ Standard Deviation of ROE. The z-score has been used in recent banking studies (Lepetit et al., 2008; Radic et al., 2012).

iiiIn particular, Section 301 of SOX Act obligates the audit committee to be comprised solely by independent members.

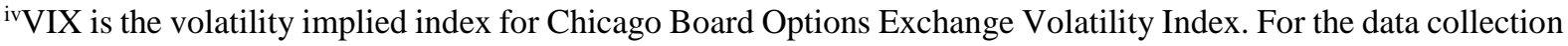
we use Bloomberg database.

vAccording to Hughes and Mester (2013, p.9-16) 'The traditional structural approach usually relies on the economics of cost minimization or profit maximization, where the performance denotes a cost function or a profit function... The non-structural approach to bank performance measurement usually focuses on achieved performance measured by a variety of financial ratios, e.g., return-on-asset, return on-equity, or the ratio of fixed costs to total costs..'

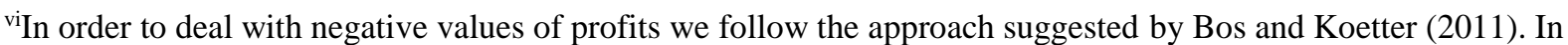
particular, negative values of profits are replaced by the value of 1 in the left had side, while simultaneously we use a new variable, namely negative profit indicator at the right hand side. This indicator in case of losses takes the absolute value of negative profits while in case of positive profits takes the value of 1 .

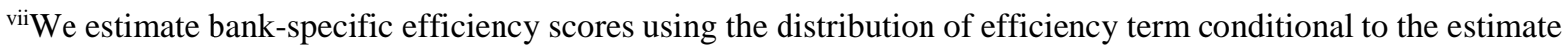
of the composite error term as in Jondrow et al. (1982).

viii For the GMM estimation we use Roodman (2009) "xtabond 2" specification in Stata.

${ }^{\mathrm{ix}}$ For the regressions where we employ EFF as a measure of bank performance, we exclude from the regression models two bank-specific control variables, FEES and EARN, which are used as outputs in the estimation of profit efficiency using SFA.

${ }^{\mathrm{x}}$ In this study, we use the model proposed by Kremer et al. (2013). That is an extension of the threshold methodology introduced by Hansen (1999). The extended method of Kremer et al. (2013) is built on the cross sectional technique of Caner and Hansen (2004), where GMM estimators are employed to account for endogeneity. As an extension to Caner and Hansen (2004) model, Kremer et al. (2013) opt for a dynamic threshold methodology. ${ }^{x i}$ We include all the explanatory variables of dynamic panel estimations apart from the crisis (CRS) dummy variable. The reason being that we opt for the threshold methodology to allow our data to determine this period 
of the turmoil through the identification of changes in the number of investment banks that belong to each regime based on threshold values of important corporate governance determinants of investment bank performance.

${ }^{x i i}$ We measure a short type regression to obtain the predicted values of the endogenous variables using a function of instruments (Caner and Hansen, 2004). As a first step, the endogenous variable is replaced with the predicted values in equation (5). As a second step, threshold value is obtained via OLS method where the threshold variable has been replaced by its predicted values estimated in the first step. The threshold value is obtained so as to minimize the concentrated sum of squared errors (Chan, 1993; Hansen, 1997). Once threshold value has been determined, the regression slopes, $\lambda_{1}$ and $\lambda_{2}$ can be estimated by employing the GMM estimator, as in Caner and Hansen (2004).

xiiiUnder the 'bad luck' hypothesis, if an unexpected exogenous to the bank financial shock increases the risk of a bank, the bank would start spending more resources in risk-monitoring operations increasing in this way its costs and consequently decreasing its net profits and performance (Berger and De-Young, 1997) .

${ }^{\text {xiv }}$ We use the natural logarithm of the board size to perform our estimation. The threshold value that is equal to 10 members (exponential value of 2.30259)

\section{NOTES ON CONTRIBUTORS/ACKNOWLEDGMENTS}

Emmanuel Mamatzakis is a professor of Finance at the University of Sussex. His research interests include efficiency/performance measurement, productivity growth, investment analysis and evaluation. He has published extensively on the efficiency of the banking industry, dynamics of UK's insurance underwriting regimes, forecasting in finance and business economics, behavioural finance (symmetric-asymmetric loss functions), credit risk and financial stability, sovereign debt crisis in the euro area, business economics (industrial productivity growth decomposition) and applied econometrics. He also serves as a Secretary General of Fiscal Policy in the Hellenic Ministry of Finance where he advises the government on public finance issues, including negotiations with the International Monetary Fund, the 
European Union and the European Central Bank. He also served as a senior economist in the Council of Economic Advisors of the Hellenic Ministry of Finance and Economics.

Theodora Bermpei is a PhD in Finance candidate at the University of Sussex. Her research interest include bank performance measurement and corporate finance related topics.

We would like to thank Professor Jens Hagendorff for providing us with his chapter Corporate Governance in Banking from the Oxford Handbook of Banking (2014). We would also like to thank one anonymous Reviewer, the Editors, and Professor Fotios Pasiouras for their valuable comments. 